\title{
New Landrevinae from Mascarene islands and little known Landrevinae from Africa and Comoros (Grylloidea: Landrevinae)
}

Sylvain Hugel

INCI, UMR 7168 / LC2, Université Louis Pasteur, CNRS; 21, rue René Descartes; F-67084 Strasbourg Cedex

\begin{abstract}
Landrevinae from Africa and south western Indian ocean (SWIO) islands are examined, seven new species and one new genus are described from la Réunion and Mauritius islands: Microlandreva parvotibialis n. sp., Creolandreva aptera n. g., n. sp., C. crypta n. sp., C. chaloupensis n. sp., $C$. crepitans n. sp., C. cocottensis n. sp., C. pollexensis n. sp. and C. brachyptera n. sp. Genitalia from Microlandreva notabilis Chopard 1958 and Oreolandreva brevipennis Chopard 1945 are illustrated and a description complement of thoracic glands and ovipositor is given. Gryllapterus tomentosus Bolivar 1912 described after an immature female was considered as a Landrevinae but is in reality a Phalangopsinae. The geographical origin of Paralandrevus hector (Saussure 1877) is corrected: erroneously described from Réunion, $P$. hector is in reality from Maluku islands. Relations between Landrevinae from Africa and SWIO islands are discussed. A key of Landrevinae from Africa and SWIO islands is given.
\end{abstract}

\begin{abstract}
Résumé. Nouveaux Landrevinae des îles Mascareignes et Landrevinae peu connus d'Afrique et des Comores (Grylloidea : Landrevinae). Les Landrevinae d'Afrique et des îles du sud ouest de l'océan indien sont étudiés, sept nouvelles espèces et un nouveau genre sont décrits de l'île de la Réunion et de l'île Maurice: Microlandreva parvotibialis n. sp., Creolandreva aptera n. g., n. sp., C. crypta n. sp., C. chaloupensis n. sp., C. crepitans n. sp., C. cocottensis n. sp., C. pollexensis n. sp. et C. brachyptera n. sp. Les genitalia de Microlandreva notabilis Chopard 1958 et Oreolandreva brevipennis Chopard 1945 sont illustrés et un complément de description des glandes thoraciques et de l'oviscapte est donné. Gryllapterus tomentosus Bolivar 1912 décrit d'après une femelle immature était considéré comme un Landrevinae mais est en réalité un Phalangopsinae. L'origine géographique de Paralandrevus hector (Saussure 1877) est corrigée : décrit par erreur de la Réunion P. hector provient des Moluques. Les relations entre les Landrevinae d'Afrique et des îles du sud est de l'océan indien sont discutées. Une clé des Landrevinae d'Afrique et des îles du sud ouest de l'océan indien est proposée.

Keywords: Orthoptera, Landrevinae, Reunion, Mauritius, endemism.
\end{abstract}

\begin{abstract}
$\mathrm{A}_{\mathrm{f}}^{\mathrm{s}}$ in other volcanic archipelagos, the flora and fauna of the Mascarene islands have evolved in isolation, resulting in unique endemic plant and animal communities. Recent field studies in the Mascarene islands (Mauritius, Réunion and Rodrigues) have allowed the record of around 90 orthopteran species in the archipelago (Hugel, pers. obs.). Two thirds of the recorded species are endemic to one of the island and a majority of these endemic species are yet undescribed (S. Hugel, in prep.). Many of these species are critically endangered; some are probably extinct (Hugel 2005).

While compiling the inventory of Orthoptera in the Mascarene archipelago, new Landrevinae crickets have been collected in both Réunion and Mauritius. Interestingly, among the $\sim 110$ known Landrevinae species (Eades \& Otte 2008), all but four species are mentioned occurring outside the Indo-Australian area: Oreolandreva brevipennis Chopard 1945 from mainland Western Africa (Cameroun); Gryllapterus tomentosus
\end{abstract}

E-mail: hugel@neurochem.u-strasbg.fr

Accepté le 15 février 2009
Bolivar 1912 from Seychelles; Microlandreva notabilis Chopard 1958 from Comoros, and Paralandrevus hector (Saussure 1877) from Réunion island.

In the first part of the present article, these four latter species, all belonging to monospecific genera, are examined. G. tomentosus was described after an immature female (Hugel, pers. obs.) the additional adult specimens collected in the type locality by Pat Matyot who gave them to Kevan (Matyot, in litt.) are clearly belonging to Phalangopsinae, and are related to other Phalangopsinae from Seychelles. This species is therefore not considered in the present study. Due to a locality label misreading, P. hector has been mistakenly described from Réunion island. This species is from Maluku islands and is therefore not further considered by the present study. Genitalia, thoracic glands and ovipositor of $O$. brevipennis and $M$. notabilis holotypes/ allotypes are illustrated and described.

In the second part of the present article, seven new species and one new genus are described from la Réunion and Mauritius islands. Microlandreva parvotibialis n. sp., Creolandreva aptera n. g., n. sp., C. crypta n. sp. and C. chaloupensis $\mathbf{n}$. sp. are described 
from Réunion island, and C. crepitans n. sp., $C$. cocottensis $\mathbf{n}$. sp. and C. brachyptera $\mathbf{n}$. sp. are described from Mauritius. Biological and ecological peculiarities on these species are given.

In the discussion section, these new species are compared to Landrevinae from neighbouring areas and a key of SWIO islands species is given.

\section{Material and methods}

The new taxa described in the present paper are based on specimens recently collected in Réunion and Mauritius islands. Sight collecting was performed by night using a halogen headlamp and a net. Specimens where also mechanically collected in a large plastic blanket while shaking plants, or brushing/removing bark.

The types of species redescribed in the present paper are in the Muséum national d'Histoire naturelle, Paris (France).

Abbreviations. A1, abdominal tergite 1; Bt, basitarsus; FW, forewing; HW, hindwing; Meso, mesonotum; Meta, metanotum; O, ovipositor; Pro, pronotum; Thx, thorax. Male genitalia. The terminology of male genitalia is after Desutter-Grandcolas (2003): dc, dorsal cavity; ec a, ectophallic apodeme; la 1, pseudepiphallic posterior sclerite lateral lobe; md l, pseudepiphallic posterior sclerite median lobe; pe, pseudepiphallic sclerite; pe a s, pseudpiphallic anterior sclerite; pe p s, pseudepiphallic posterior sclerite; pe p, pseudepiphallic parameres; ra, rami; v e s, ventral ectophallic sclerite

Measurements. The measurements have been performed on specimens stored in ethanol $70^{\circ}$. L: length; W: width; $\mathrm{H}$ : height (of pronotum lateral lobe); all in $\mathrm{mm}$.

Materiel repository. CIRAD Réunion, Centre de coopération internationale en recherche agronomique pour le développement (Réunion); CZM, Cambridge Zoological Museum (UK); LME, Lyman Entomological Museum, McGill University, QC, Canada; MNHN, Muséum national d'Histoire naturelle (France); MSIRI, Mauritius Sugar Industry Research Institute (Mauritius). Coll. S.H., Collection Sylvain Hugel, Strasbourg, France.

Scan electron microscopy. The scan electron microscope used was either a JEOL JSM-6360 in low vacuum mode, with an acceleration of $18 \mathrm{MeV}$, or a Philips XL-30 ESEM with an acceleration of $20 \mathrm{MeV}$. Specimens were directly imaged, without metallization.

Song recordings and analysis. The recordings have been performed with an Audiotechnica AT822 stereo microphone, on a HDR HC1E Sony camcorder (sampling rate: $48 \mathrm{kHz}$ ) on the nightshot mode (to follow the insect behaviour). The analysis has been performed with Origin 7 software. Song recordings are deposited in both S.H. and MNHN acoustic databases. Acoustic terminology after Ragge \& Reynolds (1998).

\section{Results}

\section{List of the Landrevinae of Africa and south western Indian Ocean islands Gryllapterus Bolivar 1912}

Gryllapterus tomentosus Bolivar 1912 [Silouhette, Seychelles] Not Landrevinae; Phalangopsinae

\section{Paralandrevus Saussure 1877}

Paralandrevus hector (Saussure 1877) [Maluku islands, not Réunion island]

\section{Oreolandreva Chopard 1945}

Oreolandreva brevipennis Chopard 1945 [Cameroun, Western Africa]

\section{Microlandreva Chopard 1958}

Microlandreva notabilis Chopard 1958 [Comoros] Microlandreva parvotibialis n. sp. [Réunion]

\section{Creolandreva n. g.}

Creolandreva aptera n. sp. [Réunion]

Creolandreva crypta n. sp. [Réunion]

Creolandreva chaloupensis n. sp. [Réunion]

Creolandreva crepitans $\mathbf{n}$. sp. [Mauritius]

Creolandreva cocottensis $\mathbf{n}$. sp. [Mauritius]

Creolandreva brachyptera n. sp. [Mauritius]

\section{Genus Gryllapterus Bolivar 1912}

Gryllapterus tomentosus Bolivar 1912: 284.

Type species. Gryllapterus tomentosus Bolivar 1912; Otte 1988: 284, 327.

Monospecific genus.

Distribution. Indian Ocean, Seychelles, Silouhette island, near Mt. Pot-à-Eau.

\section{Gryllapterus tomentosus Bolivar 1912}

Gryllapterus tomentosus Bolivar 1912: 285.

Material examined. Upublished pictures of the holotype (CZM) labelled: Silhouette, '08., Seychelles Exp; Gryllapterus tomentosus, Bolivar Cotype [manuscript]. 2へ̂, 4ㅇ, Seychelles, Silouhette, VIII.1990. P. Matyot coll; Lot No.1; Gryllapterus tomentosus Bol. [manuscript], Det. D. K. Mc. E Kevan; LME.

This species is described after a single non adult female (Hugel, pers obs. after unpublished pictures of the holotype). Chopard (1967) considered it as a Gryllomorphini; subsequently, Gorochov (1982) placed it in Landrevinae, and independently Otte \& Alexander (1983) considered this species as a Landrevini.

Adult specimens collected in the type locality by Pat Matyot who gave them to Keith Kevan (Matyot, in litt.) are clearly belonging to $G$. tomentosus and have been labelled as such by Keith Kevan.

With bristles on the dorsum of the head; spines above, and few spines between most of tibia III subapical spurs; male genitalia and metanotal glands closely resembling those of Phalangopsinae from Seychelles (Gorochov 2006), this species clearly belongs to Phalangopsinae and will be redescribed elsewhere (S. Hugel, in prep). 


\section{Genus Paralandrevus Saussure 1877}

Paralandrevus Saussure 1877: 439; Kirby 1906: 50; Otte 1988: 284.

Type species. Landrevus hector, Saussure 1877

Monospecific genus.

Distribution. NOT Réunion island; Maluku islands, Buru.

\section{Paralandrevus hector (Saussure 1877)}

Saussure 1877: 440 (original description).

Material examined. Female holotype (MNHN), labelled: Bourou, Moll?ques, Durv.; 334.

Type locality. In Saussure's original description, this species is mentioned from Bourbon, the former name of Réunion island. However, the specimen is labelled: "Bourou Mol?ques Durv." where "?" corresponds to the perforation of the insect pin. This suggests that Paralandrevus hector type locality may be on Buru (Bourou), one of the Maluku islands (Moluques), and not Réunion island.

In addition, this species has not been collected in the numerous intensive field work lead these last years in Réunion island.

Moreover, $P$. hector tibia III lacks the spine between the most proximal outer subapical spurs characteristic of most SWIO islands Landrevinae.

\section{Genus Oreolandreva Chopard 1945}

Type species. Oreolandreva brevipennis Chopard 1945: 170; Otte 1988: 284, 327.

Monospecific genus.

Distribution. Africa, Cameroun, Mont Cameroun.

Diagnosis. Elytra short, rounded in both gender with a parallel venation, without any stridulatory device in male. Tibia I without tympanum. Tibia III with 2 inner apical spurs (3 in Microlandreva and Creolandreva). Male with dorsal glands on metanotum forming 2 pits rimmed by setae (fig. 1). Female ovipositor dorsal valves apex with a longitudinal discontinuity on its outer side; ventral valves without transversal preapical notch in the ventral margin (fig. 2). Oreolandreva and Microlandreva are distinguished from all other Landrevinae genera by the pseudepiphallic sclerite containing two dorsomedially articulated sclerites (fig. 12-14, 15-20 respectively); the anterior pseudepiphallic sclerite is short and thick in Oreolandreva (side view, fig. 13) whereas it is long and thin in Microlandreva (fig. 16, 19). Oreolandreva can also be distinguished from Microlandreva by the above-mentioned dorsal glands and ovipositor characters.

\section{Oreolandreva brevipennis Chopard 1945 (figs. 1, 2, 12-14)}

Oreolandreva brevipennis Chopard 1945: 171.

Material examined. Type material (MNHN), 2ð, 4q, Africa, Mont Cameroun, versant S.-E., 1800-2000 m.

Description complement Male. Genitalia (fig. 12-14). Bilaterally symmetrical. Pseudepiphallic anterior sclerite widened and back-curved anteriorly. Pseudepiphallic posterior

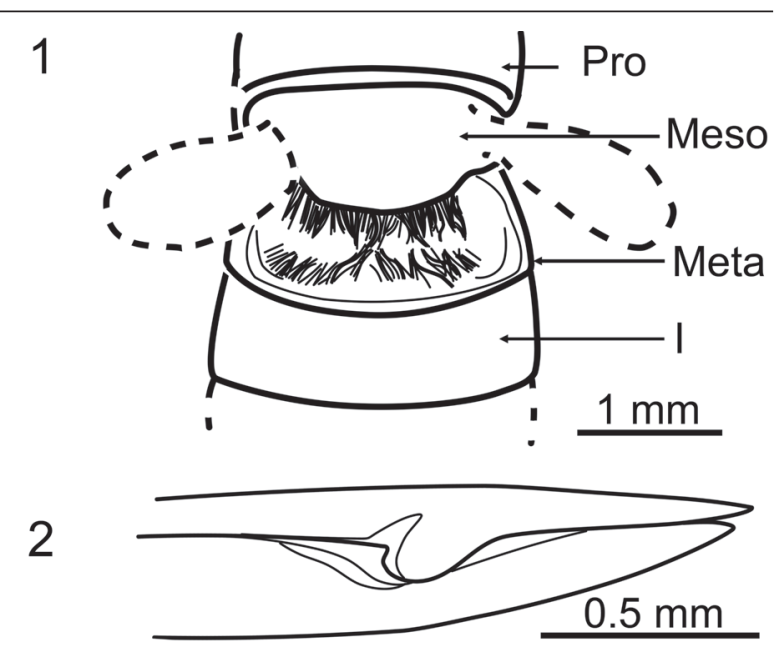

Figure 1-2

Oreolandreva brevipennis. 1, dorsal view of mesothoracic, metathoracic and first abdominal tergites of male paratype. 2, tip of female allotype ovipositor in right lateral view. Abbreviations: see material and methods.

sclerite enveloping posterior apex of pseudepiphallic anterior sclerite; with two weakly sclerotized mediodorsal lobes oriented anteriorly. Ventral ectophallic sclerites extremely elongated; connected to ectophallic apodemes near the arch; reaching almost the anterior tip of ectophallic apodemes; articulated with anterior part of pseudepiphallic parameres. Ectophallic apodemes not reaching the anterior tip of the rami. Dorsal cavity present.

Female. Ovipositor (fig. 2). Apex of dorsal valves with a longitudinal discontinuity on its outer side; ventral valves without a transversal preapical notch in the ventral margin.

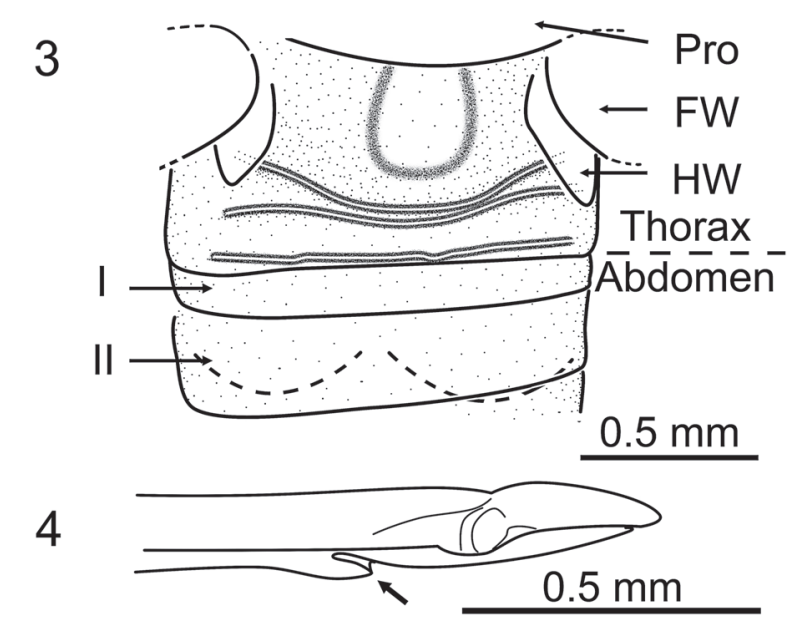

Figure 3-4

Microlandreva notabilis. 3, dorsal view of mesothoracic, metathoracic and first abdominal tergites of male holotype. The dotted line indicates the posterior limit of forewings when closed. 4, tip of female allotype ovipositor in lateral view. The arrow indicates the ventral notch in the ventral valves. Abbreviations: see material and methods. 

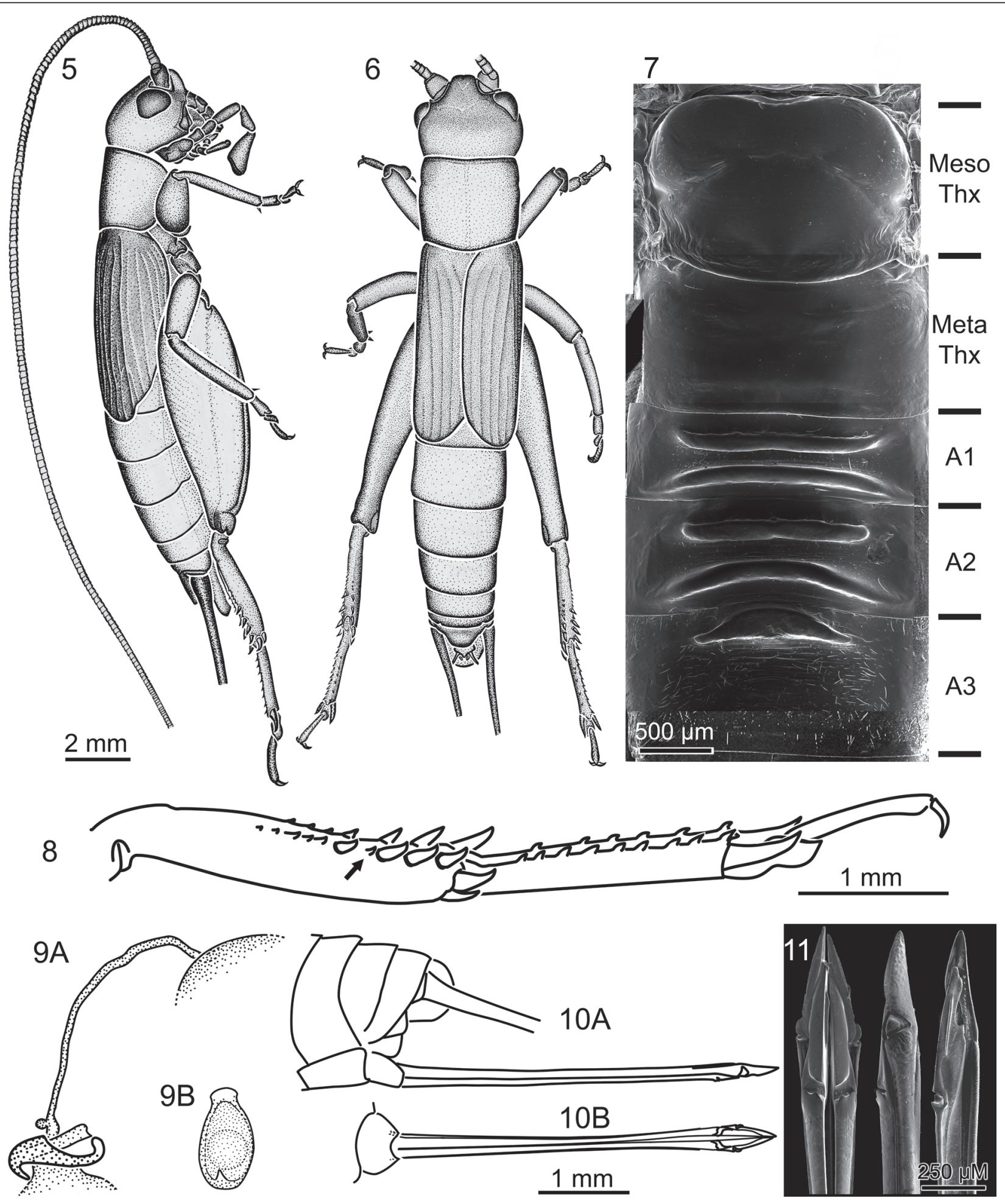

Figure 5-11

Microlandreva parvotibialis n. sp. 5-8 male holotype. 5, lateral habitus. 6, dorsal habitus. 7, scan electron microscope dorsal view of mesothoracic, metathoracic and abdominal tergites 1-3. 8, external lateral view of tibia and tarsus III. The arrow indicates the spine intercalated between subapical spurs. 9-11 female allotype. 9, copulatory papilla in right lateral (A) and ventral (B) views. 10, ovipositor in lateral (A) and ventral (B) views. 11, scan electron microscope views of ovipositor ventral (left) lateral (middle) and internal (right) tip. Abbreviations: see material and methods. 


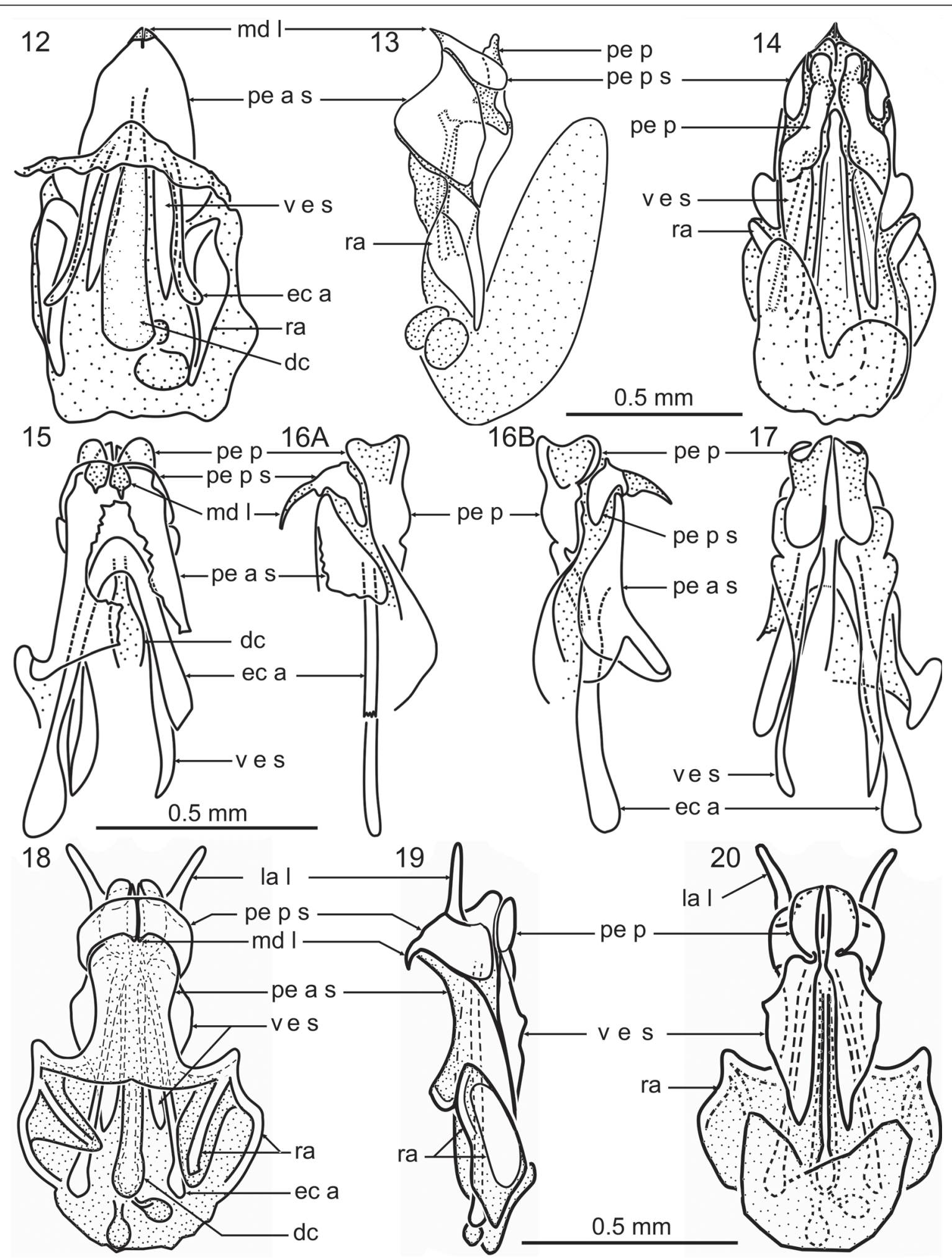

Figure 12-20

Male genitalia of Oreolandreva (12-14) and Microlandreva (15-20) species in dorsal $(12,15,18)$, lateral $(13,16,19)$ and ventral $(14,17,20)$ views. 12-14, Oreolandreva brevipennis n. sp. male paratype. 15-17, M. notabilis n. sp. male holotype. 18-20, M. parvotibialis n. sp. male holotype. Abbreviations: see material and methods. 


\section{Genus Microlandreva Chopard 1958}

Type species. Microlandreva notabilis Chopard 1958: 19.

Distribution. Indian Ocean, Comoros, Réunion island.

Two species are included within this genus $M$. notablis and $M$. parvotibialis n. sp..

Diagnosis. Elytra short, strait, both gender with a parallel venation, no stridulatory device in male. Tibia I with or without tympanum. Tibia III with 3 inner apical spurs. Male with dorsal glands forming fold-like transverse elevations on metanotum or abdominal tergites (fig. 3, 7). Female ovipositor dorsal valves apex with a longitudinal discontinuity on its outer side; ventral valves with a transversal preapical notch in the ventral margin (fig. 4, 11). Microlandreva and Oreolandreva are distinguished from all other Landrevinae genera by the pseudepiphallic sclerite containing two dorsomedially articulated sclerites (fig. 15-20, 12-14 respectively); the anterior pseudepiphallic sclerite is long and slender in Microlandreva (side view, fig. 16, 19), whereas it is short and thick in Oreolandreva. Microlandreva can also be distinguished from Oreolandreva by the above-mentioned dorsal glands and ovipositor characters.

\section{Microlandreva notabilis Chopard 1958 (figs. 3, 4, 15-17)}

Microlandreva notabilis Chopard 1958: 19.

Type locality. Indian Ocean, Comoros, Moheli, Kangani.

Material examined. Type material (MNHN) $1 \delta, 1 q$, Moheli, Kangani; A. Robinson coll.

Description complement. Male. Thorax. Metathoracic glands forming 3 fold-like transverse elevations (fig. 3). Genitalia (fig. 15-17). Anterior part damaged in M. notabilis holotype. Bilaterally symmetrical. Pseudepiphallic sclerite containing two sclerites articulated dorsomedially. Pseudepiphallic anterior sclerite widened and back-curved anteriorly, with perhaps a dorsal fenestration on the middle (or pseudepiphallus damaged?). Pseudepiphallic posterior sclerite enveloping posterior apex of pseudepiphallic anterior sclerite; with two weakly sclerotized mediodorsal lobes oriented anteriorly. Ventral ectophallic sclerites extremely elongated; connected to ectophallic apodemes near the arch; reaching almost the anterior tip of ectophallic apodemes; articulated with anterior part of pseudepiphallic parameres. Ectophallic apodemes long, laterally flattened. Rami damaged. Dorsal cavity present, narrow; anterior tip damaged. Female. Ovipositor (fig. 4). Apex of dorsal valves with a longitudinal discontinuity on its outer side; ventral valves with a transversal preapical notch in the ventral margin.

\section{Microlandreva parvotibialis n. sp. Figs. 5-11, 18-20; tab. 1)}

Holotype. Male. Indian Ocean, Mascarene archipelago, Réunion island, Saint-Philippe, Basse Vallée, Vallée Heureuse, rempart Est, sentier du Puys Ramond; 700-800 m alt. 29.I.2005. N. Cliquennois, MNHN (MNHN-ENSIF2052).

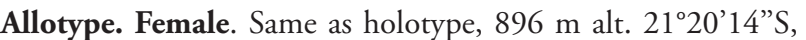
55'42'15”E; 11.XII.2005. S. Hugel, MNHN (MNHNENSIF2053).

Description. Head. Not prognathous; with fine setae; without dorsal bristles; rostrum in dorsal view as wide as antennal scape (fig. 6), and 0.26 times as wide as the head (fig. 6), markedly protruding in side view (fig. 5); epistomal suture complete. Antenna $>12.4 \mathrm{~mm}$ long, inserted between the eyes, not beneath the middle of the face. Maxillary palpi particularly long; $3^{\text {rd }}$ article as long as the $4^{\text {th }} ; 4^{\text {th }}$ slightly widened apically; $5^{\text {th }} 1.6$ times as long as the $4^{\text {th }}$, twice as long as wide subapically (fig. 5). Legs. Short. Coxa I with a dorso-apical triangular notch. Tibia I with oval inner tympanum and without outer tympanum. Tibia I with two ventral apical spurs, one on each side, the anterior (inner) longer than the posterior (outer); tibia II with two ventral apical spurs equal in size, one on each side. Tibia III half as long as femur III; with relatively short spurs; with 3 inner and 3 outer apical spurs; inner apical spurs with the upper the longest; outer apical spurs with the median the longest; inner lower (inner spur 1) apical spur half as long as the outer lower (outer spur 1) apical spur; with 3 inner and 3 (male holotype) or 4 (female allotype) outer subapical spurs, with one spine between the most proximal subapical spurs (i.e. between subapical spurs 2 and 3 on male holotype (fig. 8) and between subapical spurs 3 and 4 on female allotype). Hindbasitarsus elongated, only slightly shorter than tibia III; with 9-10 dorsal spines on the outer carina and 6-7 spines on the inner carina; with one long apical spur on each side (fig. 8). Tarsal claws neither serrulated nor bifurcated. Arolium relatively reduced. Wings. Identical in both genders. Tegmina reduced, reaching the posterior margin of tergite 3; with 5 longitudinal veins in the dorsal field and 7 in the lateral field; without transverse veins (fig. 6). Hindwings present, slightly shorter than the tegmina. Color. General coloration yellowish-grey with darker spots. Face and rostrum shiny black. Tibiae I, II, III and femora I and II with dark bands. Femora III with fine outer stripes.

Male. Thorax. Metathoracic glands absent (fig. 7). Tegmina. No stridulatory apparatus. Abdomen with dorsal glands on the first three tergites (fig. 7), completely covered by the forewings. On tergites 1 and 2, glands forming two fold-like transverse elevations; on tergite 3 , glands as a single elevation thicker medially and fitting in the concave posterior margin of tergite 2 (fig. 7). Subgenital plate rounded apically. Last abdominal tergite rounded apically. Cerci damaged in the specimen, $>4$ $\mathrm{mm}$ long. Genitalia (fig. 18-20). Bilaterally symmetrical. Pseudepiphallic sclerite containing two sclerites articulated dorsomedially. Anterior pseudepiphallic sclerite elongate, widened and back-curved anteriorly. Posterior pseudepiphallic sclerite enveloping the posterior border of anterior sclerite;

Table 1. Measurements (mm) of Microlandreva parvotibialis $\mathbf{n} . \mathbf{s p}$.

\begin{tabular}{|c|c|c|c|c|c|c|c|c|c|c|c|c|c|c|c|}
\hline & \multirow{2}{*}{$\begin{array}{c}\text { Body } \\
\text { L }\end{array}$} & \multicolumn{2}{|c|}{ Head } & \multicolumn{3}{|c|}{ Thorax } & \multicolumn{3}{|c|}{ Tibia } & \multicolumn{3}{|c|}{ Femora } & \multirow{2}{*}{ Bt III } & \multirow{2}{*}{$\begin{array}{c}\text { FW } \\
\text { L }\end{array}$} & \multirow{2}{*}{$\begin{array}{l}\mathrm{O} \\
\mathrm{L}\end{array}$} \\
\hline & & $\mathrm{L}$ & W & $\mathrm{L}$ & W & $\mathrm{H}$ & I & II & III & I & II & III & & & \\
\hline ô Holotype & 15.9 & 2.1 & 2.6 & 2.1 & 2.5 & 1.4 & 2.1 & 2.2 & 2.4 & 2.0 & 2.1 & 7.2 & 2.7 & 5.0 & - \\
\hline O Allotype & 15.5 & 3.1 & 3.9 & 2.5 & 3.2 & 1.8 & 2.7 & 3.1 & 3.4 & 2.6 & 2.6 & 8.3 & 3.2 & 7.1 & 8.3 \\
\hline
\end{tabular}



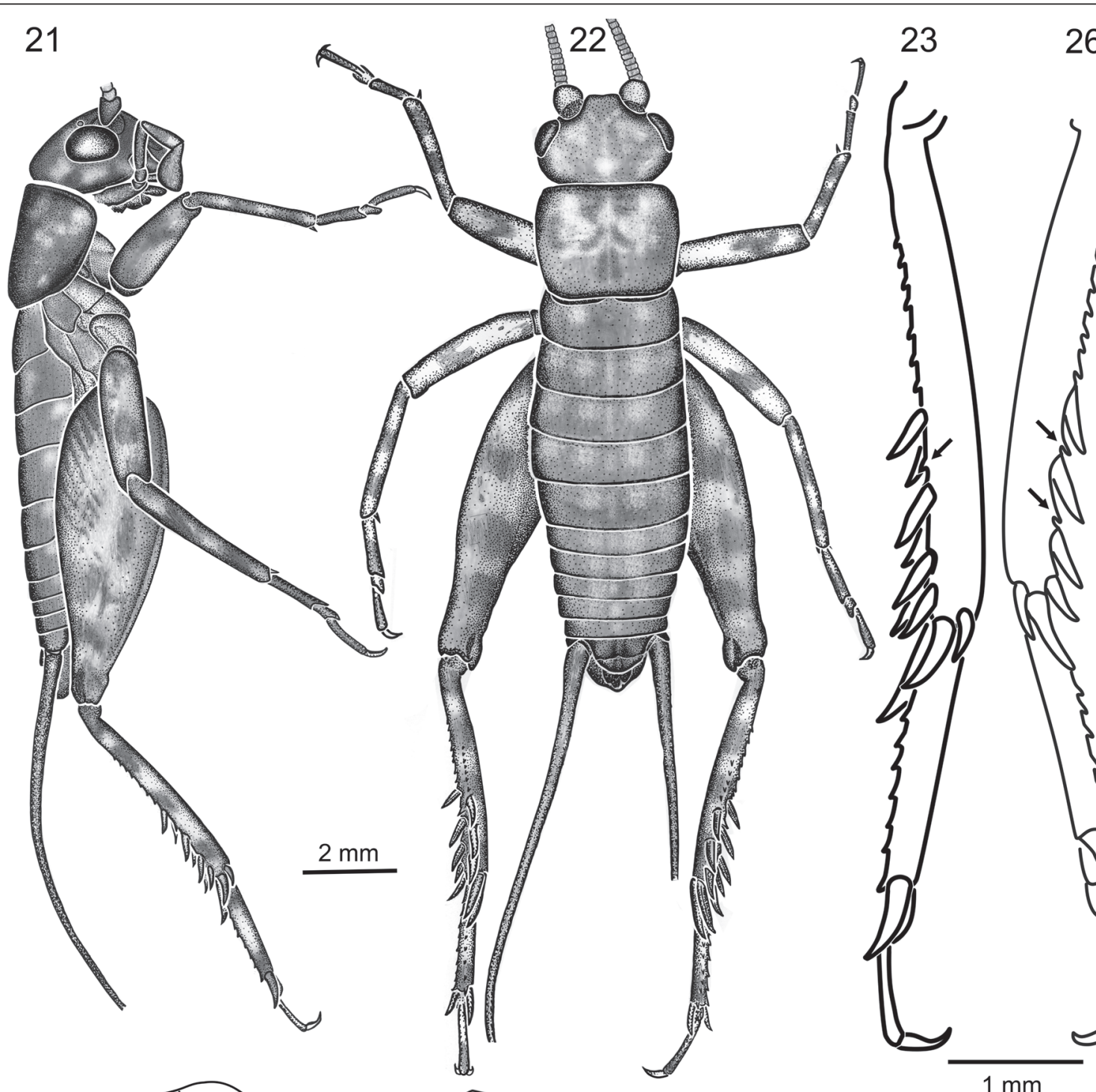
with two weakly sclerotized mediodorsal lobes oriented anteriorly; with two horn-like lateral lobes oriented backwards. Ventral ectophallic sclerites extremely extended; connected to ectophallic apodemes near the arch; reaching the middle of the rami; articulated with anterior part of pseudepiphallic parameres. Ectophallic apodemes long and thin, club-like. Endophallic sclerite extremely reduced, simple and median, close to ectophallic fold, not U-shaped, covering the posterior part of the dorsal cavity, more sclerified laterally than dorsally, without obvious apodeme. Dorsal cavity narrow and long, reaching the anterior tip of ectophallic apodemes.

Female. Tibia III with the third outer subapical spur half as long as the second. Abdomen without dorsal glands. Subgenital plate with a shallow emargination (fig. 10B). Cerci as in $\delta$ holotype, > $11.5 \mathrm{~mm}$. Ovipositor strait, not widened in lateral view (fig. 10A), apex widened in ventral view (fig. 10B); dorsal valves slightly higher than ventral valves (fig. 10B); dorsal and ventral valves immovably connected to each other; right and left valves not immovably connected; in the apex dorsal valves wrapped around ventral valves and entirely covering them (fig. 11) inner side of dorsal valves transversally plicate (fig. 11); apex of dorsal valves with a longitudinal discontinuity on its outer side (fig. 11); dorsal margin of dorsal valve apex smooth (fig. 11); tip of dorsal valves pointed; ventral valves with a transversal preapical notch in the ventral margin (fig. 11), anterior margin of the notch bilobated (fig. 11). Copulatory papilla. Bilaterally subsymmetrical (fig. 9B), ellipsoid in dorsal view with the anterior tip slightly protruding (fig. 9A). Anterior tip dorsally strongly sclerotized, upturned towards the apex in an antero-dorsal protrusion (in lateral view, fig. 9A); central part less sclerotized; posterior tip turned ventrally in a spiny postero-ventral protrusion (fig. 9).

Biology. The $\widehat{\sigma}$ holotype has been collected during night time by whipping the ground vegetation. In spite of multiple intensive whipping sessions in this area, only one single male has been collected, suggesting that this observation may not correspond to the very habitat of the species. The $q$ allotype has been collected by night, still alive in a spider's web, which was attached to dead leaves of tree ferns at $1.5 \mathrm{~m}$ high. We however failed to found more specimens in the hollow shaft of dead tree fern leaves.

As we have not directly observed living specimens, we can only speculate after their biology. The dorsum of head flattened, the short legs I and II, the hindleg with tibia III much shorter than femora III, the absence of stridulum and the location of male dorsal glands on the abdominal, not thoracic, tergites, could be more or less associated with confined habitats. This would agree Otte (1988)'s observations on other Landrevinae species, which he called "bark crickets" according to their under barks living habits.

\section{Genus Creolandreva n. g.}

Type species. Creolandreva aptera n. g. n. sp. here designated.

Distribution. Indian Ocean, Mascarene archipelago, Réunion island, Mauritius.

Diagnosis. As Microlandreva and Oreolandreva, Creolandreva n. g. male genitalia are distinguished from all other Landrevinae genera genitalia by the rami with two distinct sclerites: an elongated dorsally and an ovoid laterally. As Microlandreva parvotibialis n. sp., Creolandreva n. g. is characterized by the occurrence of one spine between at least the most proximal outer subapical spurs of tibia III. Creolandreva n. g. is distinguished from Microlandreva and Oreolandreva by: the pseudepiphallus comprising one single sclerite with a deep posterior notch; the ventral ectophallic sclerites moderately extended, only half as long as ectophallic apodemes; the lack of glandular structures on male metanotum and tergites, even in winged species. It can be additionally separate from Oreolandreva by the number of inner apical spurs of tibia III (3 instead of 2).

Description. Head. Head flattened dorsally. Eyes only slightly protruding. Not prognathous; with fine setae and very few small dorsal bristles; rostrum in dorsal view wider than antennal scape, with small bristles on its sides. Antenna inserted between the eyes, not beneath the middle of the face. Maxillary palpi particularly long. Wings present or absent. Hindwings present when forewings present. Legs Coxa I with a dorso-apical triangular notch. Tibia I either without tympanum or with inner tympanum only or with inner and outer tympana (in singing species); never with outer tympanum only. Tibia I with basitarsus of normal size (not reduced). Tibia I with two ventral apical spurs, one on each side, the anterior (inner) longer than the posterior (outer); tibia II with two ventral apical spurs equal in size, one on each side. Tibia III with relatively short spurs; with 3 inner and 3 outer apical spurs; inner apical spurs with the upper the longest; outer apical spurs with the median the longest; inner lower (inner spur 1) apical spur half as long as the outer lower (outer spur 1) apical spur; with 3 inner and 3 outer subapical spurs, with one spine between the most proximal outer subapical spurs (i.e. at least between subapical spurs 2 and 3, fig. 23, 29, 40, 48 and 53). Hindbasitarsus, half as long as tibia III. Tarsal claws neither serrulated nor bifurcated. Arolium reduced.

Male. Thorax. Metanotum without obvious glands. Wings. When present, forewings with or without stridulatory device. Abdomen without dorsal glands. Epiproct slightly concavous. Subgenital plate not notched. Genitalia As in fig. 30-37 and 56-64. Bilaterally symmetrical. Pseudepiphallic sclerite not separated into a posterior and anterior part; widened and back-curved anteriorly, slightly longer than the rami; with a medioposterior notch; with paired process on the basis of the notch (pseudepiphallic sclerite median lobes), except in C. crepitans $n$. sp. where the processes are on the sides of the notch (fig. 56). Ectophallic apodemes long, laterally flattened, reaching the anterior margin of the rami. Rami with two distinct sclerites: an elongated dorsally and an ovoid laterally. Ventral ectophallic sclerites elongated; connected to ectophallic apodemes near the arch; reaching the middle of ectophallic apodemes; articulated with anterior part of pseudepiphallic parameres.

Female. (female C. chaloupensis n. sp. is unknown). Ovipositor. apex of dorsal valves with a longitudinal discontinuity on its outer side (fig. 25C, 50B, 55B); ventral valves without transversal preapical notch in the ventral margin.

Etymology. After the words "creole" and "Landreva".

Biology. Creolandreva n. g. species are strictly nocturnal crickets, living within plant material such as mosses, lichens and aerial litter covering endemic trees such as Myrtaceae, Melastomataceae, etc. (C. aptera n. sp., C. 
crepitans n. sp.); within dead sections and under barks of endemic Sapotaceae (C. crepitans n. sp.); and within dead sections of endemic Myrtaceae (C. aptera n. sp., C. crepitans n. sp., C. cocottensis n. sp., C. brachyptera n. sp.). Except $C$. aptera n. sp. occurring sometimes near the ground (during both day and night), all Creolandreva n. g. species have been recorded between 0.5 and 4 meters (during both day and night), and might exist in the canopy as well. Whereas many unoccupied branches have been observed, most Creolandreva n. g. specimens have not been found alone within the same branches, suggesting a gregarious behaviour. In addition, two species have been found occurring together $(C$. brachyptera n. sp. and C. cocottensis n. sp.). All but one species (C. chaloupensis n. sp.) are living in wet areas, but this might be linked to the poor preservation of dry forests and savannas in the archipelago.

\section{Creolandreva aptera $\mathbf{n}$. sp.} (figs. 21-25, 33-35; tab. 2)

Holotype. Male. Indian Ocean, Mascarene archipelago, Réunion island, Saint-Philippe, Basse Vallée, Vallée Heureuse, rempart Est, sentier du Puys Ramond; 700-896 m alt.; 11.XII.2005. S. Hugel, MNHN (MNHN-ENSIF2054).

Allotype. Female. same as holotype, Saint-Philippe, Basse Vallée, Vallée Heureuse, $750 \mathrm{~m}$ alt.; $21^{\circ} 20^{\prime} 16^{\prime \prime} S$, 5542'21'E; 11.XII.2005. S. Hugel, MNHN (MNHN-ENSIF2055).

Paratypes. Male. same as holotype, Bras-Panon, Plaine des lianes, forêt de la cascade du Chien, $765 \mathrm{~m}$ alt.; $21^{\circ} 02^{\prime} 05^{\prime \prime} \mathrm{S}$ 55³6’23”E; 20.XII.2005. S. Hugel, S. Hugel Coll. Females. 2 , same as holotype, Bras-Panon, Plaine des lianes, forêt de la cascade du Chien, $765 \mathrm{~m}$ alt.; $21^{\circ} 02^{\prime} 05^{\prime \prime} \mathrm{S} 55^{\circ} 36^{\prime} 23^{\prime \prime} \mathrm{E}$;

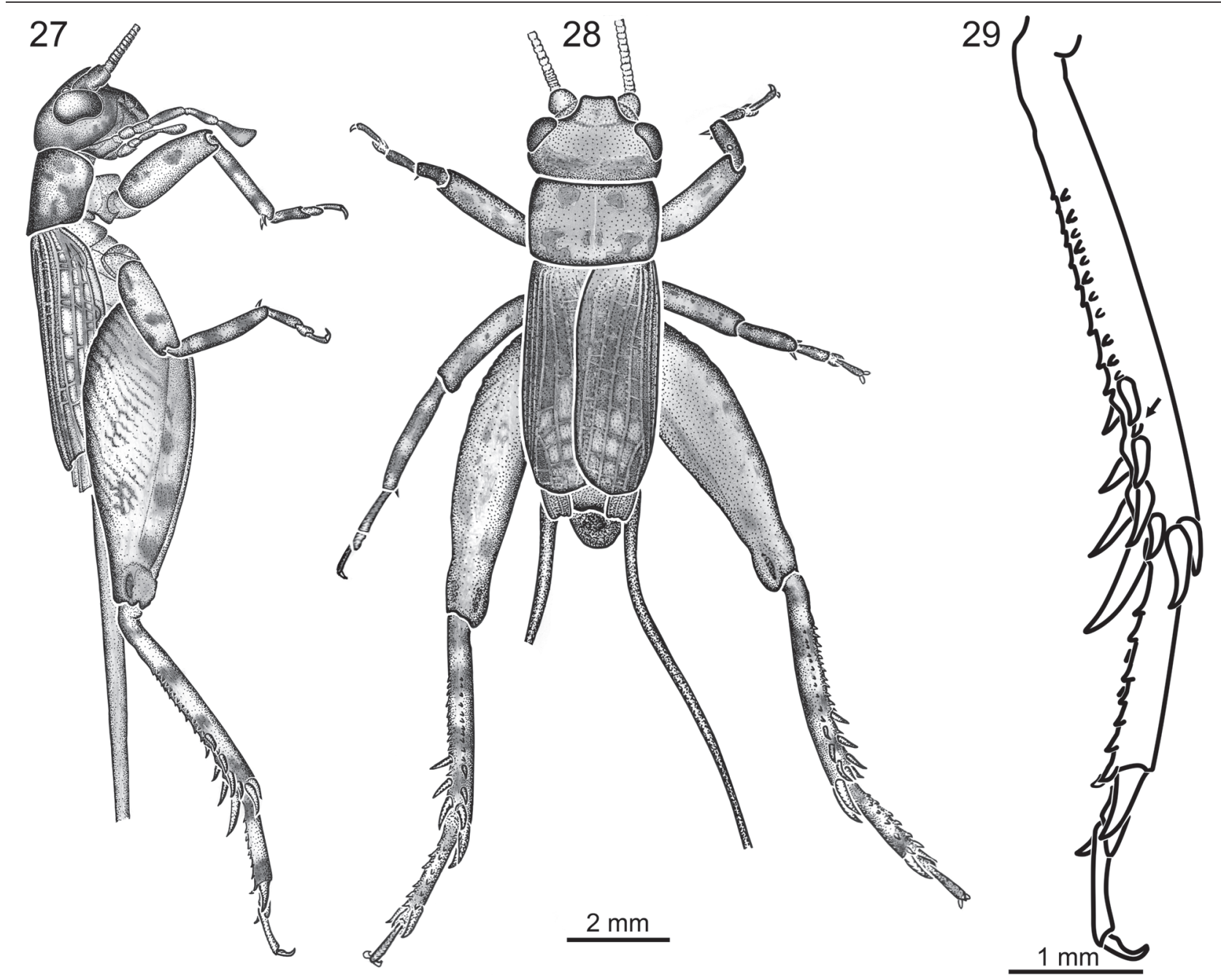

Figure 27-29

Creolandreva chaloupensis n. g., n. sp. male holotype. 27, lateral habitus. 28, dorsal habitus. 29, external lateral view of tibia and tarsus III. The arrow indicates the spine intercalated between subapical spurs. 

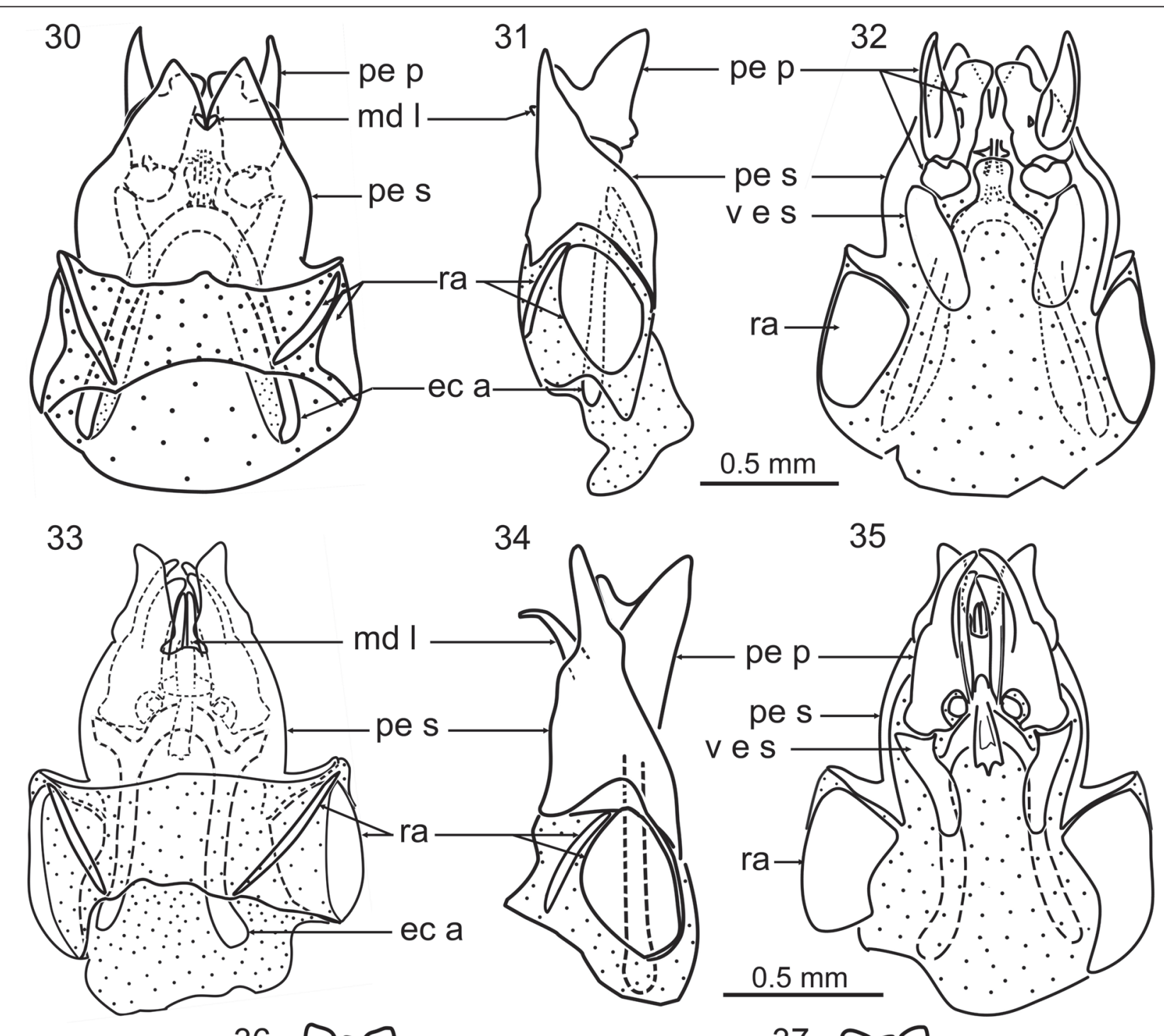

34

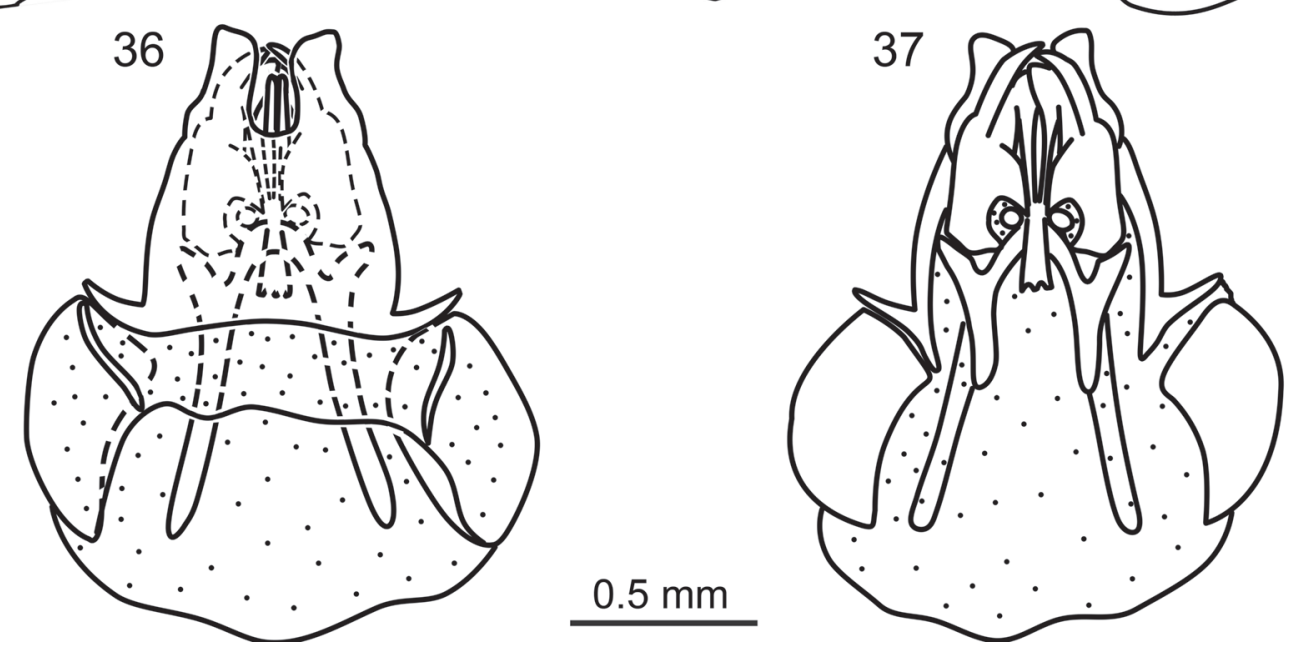

Figure 30-37

Male genitalia of Creolandreva n. g. species from la Réunion in dorsal $(30,33,36)$ lateral $(31,34)$ and ventral $(32,35,37)$ views. 30-32, C. chaloupensis $\mathbf{n}$. sp. male holotype. 33-35, C. aptera n. sp. male holotype. 36-37, C. crypta n. sp. male holotype. Abbreviations: see material and methods. 
Table 2. Measurements (mm) of Creolandreva aptera n. g., n. sp.

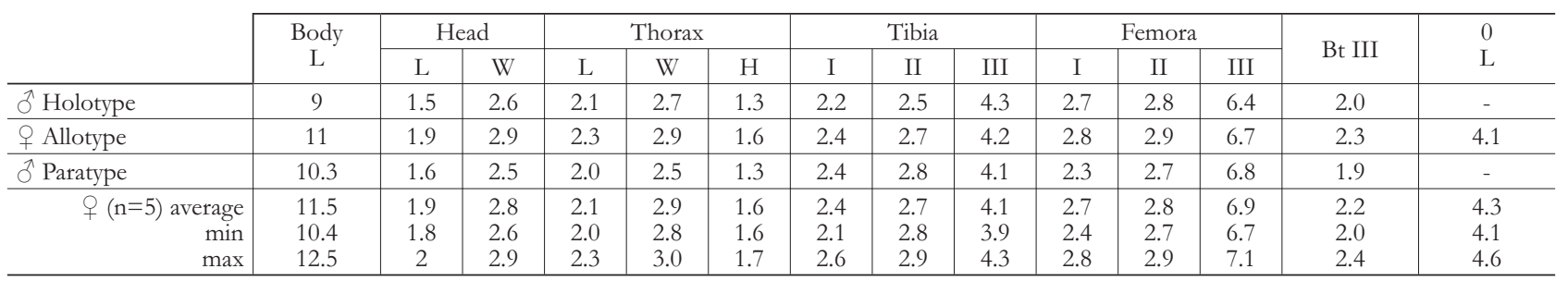

\section{IV.2007. S. Hugel, CIRAD Réunion \& S. Hugel Coll.}

$1+$, same as holotype, Saint-Philippe, Basse Vallée, Vallée Heureuse, sentier de la source Repiquet 805 m alt.; 2119'33"S 5541'52”E; 12XII.2005. S. Hugel, S. Hugel Coll.

2 ㅇ, same as holotype, Saint-Philippe, Basse Vallée, Vallée

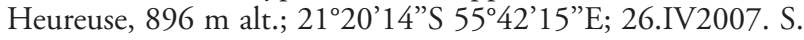
Hugel, MSIRI (Mauritius) \& S. Hugel Coll.

Description. Head. Rostrum narrow; apex inconspicuously concave in dorsal view (fig. 22), only slightly protruding in side view; frons convex in side view (fig. 21). Antenna $>25 \mathrm{~mm}$ long. Thorax. Pronotum 1.23-1.40 times as wide as long in dorsal view (holotype: 1.25; allotype: 1.26).

Legs. Tibia I without tympanum. Tibia III 0.68 times as long as femur III; with 5-7 dorsal spines above the inner subapical spurs; with 6-9 dorsal spines above outer subapical spurs.

Hindbasitarsus with 7-9 dorsal spines on the outer carina and 5-7 spines on the inner carina; with one long apical spur on each side (fig. 23). Wings. Tegmina inconspicuous, squamiform, $<0.2 \mathrm{~mm}$ long in both male and female; barely protruding beyond pronotum (fig. 22). Hindwings absent. Cerci $>8 \mathrm{~mm}$ long. Color. General coloration grey-blackish with lighter spots. Face and rostrum shiny black. Tibiae I, II, III and hind basitarsus yellowish-grey with dark bands. Femora III with fine outer stripes.

Male. Head. 0.21-0.23 times as wide as the head (holotype: 0.21 ). Maxillary palpi $3^{\text {rd }}$ article $0.90-1.00$ times as long as the $4^{\text {th }}$ (holotype: 0.90 ); $4^{\text {th }} 0.74-0.84$ times as long as the $5^{\text {th }}$ (holotype: 0.84$) ; 5^{\text {th }} 2.2$ times as long as wide subapically (holotype: 2; fig. 21). Thorax. Pronotum 1.24-1.25 times as wide as long in dorsal view (holotype: 1.25). Metathoracic glands absent. Abdomen without dorsal glands. Genitalia (fig. 33-35). Pseudepiphallic sclerite with a deep posterior median notch; with two weakly sclerotized mediodorsal digitations directed upwards. Pseudepiphallic parameres with 2 posterior lobes: the ventral lobe laterally flattened; the dorsal dorsoventrally flattened. Antero median part of pseudepiphallic parameres surrounding a circular sclerification.
Female. Head. 0.19-0.23 times as wide as the head (allotype: 0.19 Maxillary palpi $3^{\text {rd }}$ article $0.83-1.00$ times as long as the $4^{\text {th }}$ (allotype: 0.94$) ; 4^{\text {th }} 0.75-0.86$ times as long as the $5^{\text {th }}$ (allotype: $0.80) ; 5^{\text {th }} 2.4$ times as long as wide subapically (allotype: 2.0 ). Thorax. Pronotum 1.26-1.40 times as wide as long in dorsal view (allotype: 1.26). Abdomen. Subgenital plate without emargination (fig. 25B). Cerci as in $\widehat{O}$ holotype, $>9 \mathrm{~mm}$. Ovipositor strait, not widened in ventral view (fig. 25B), apex slightly widened in side view (fig. 25A, 25C); dorsal and ventral valves immovably connected to each other; right and left valves not immovably connected; in the apex dorsal valves are wrapped around ventral valves; ventral valve apex covered by the dorsal valves; apex of dorsal valves with a longitudinal discontinuity on its outer side (fig. 25C); dorsal margin of dorsal valve apex rough; tip of dorsal valves pointed; ventral valves without transversal preapical notch in the ventral margin (fig. 25B, C). Copulatory papilla. Bilaterally subsymmetrical in dorsal view (fig. 24C), with an anterior protrusion forming an anterior ventral plate weakly sclerotized.

Biology. This inconspicuous species has been found during both day and night under barks, in dead trunks and within deep moss layers covering branches in preserved upland forests. It has been seldom observed on plant surface (trunks, ferns, etc.) before the end of the night. Creolandreva aptera $\mathbf{n}$. sp. occurs from near the ground to $\sim 4 \mathrm{~m}$. I observed every stage in all localities in both December and April, suggesting the presence of adults throughout the year.

\section{Creolandreva crypta n. sp. (figs. 26, 36, 37; tab. 3)}

Holotype. Male. Indian Ocean, Mascarene archipelago, Réunion island, Sainte-Rose, Réservoirs. $869 \mathrm{~m}$ alt.; $21^{\circ} 09^{\prime} 37^{\prime \prime} \mathrm{S}$ 554'38”'E; 20.XII.2005, S. Hugel, MNHN (MNHNENSIF2056).

Table 3. Measurements (mm) of Creolandreva crypta n. g., n. sp.

\begin{tabular}{|c|c|c|c|c|c|c|c|c|c|c|c|c|c|c|}
\hline & \multirow{2}{*}{$\begin{array}{c}\text { Body } \\
\text { L }\end{array}$} & \multicolumn{2}{|c|}{ Head } & \multicolumn{3}{|c|}{ Thorax } & \multicolumn{3}{|c|}{ Tibia } & \multicolumn{3}{|c|}{ Femora } & \multirow{2}{*}{ Bt III } & \multirow{2}{*}{$\begin{array}{l}0 \\
\mathrm{~L}\end{array}$} \\
\hline & & $\mathrm{L}$ & $\mathrm{W}$ & $\mathrm{L}$ & $\mathrm{W}$ & $\mathrm{H}$ & I & II & III & I & II & III & & \\
\hline$\widehat{\jmath}$ Holotype & 10.2 & 1.5 & 2.3 & 1.7 & 2.3 & 1.2 & 2.2 & 2.6 & 3.4 & 2.3 & 2.3 & 5.8 & 1.9 & - \\
\hline q Allotype & $7.5^{*}$ & 1.9 & 2.6 & 1.9 & 2.7 & 1.3 & 2.3 & 2.7 & 3.9 & 2.3 & 2.4 & 7.0 & 2.0 & $3.6^{* *}$ \\
\hline
\end{tabular}

${ }^{*}$ specimen shrunken; ${ }^{* *}$ the ovipositor is rolled. 
Table 4. Measurements ( $\mathrm{mm}$ ) of Creolandreva chaloupensis n. g., n. sp.

\begin{tabular}{|c|c|c|c|c|c|c|c|c|c|c|c|c|c|c|}
\hline & \multirow{2}{*}{$\begin{array}{c}\text { Body } \\
\text { L }\end{array}$} & \multicolumn{2}{|c|}{ Head } & \multicolumn{3}{|c|}{ Thorax } & \multicolumn{3}{|c|}{ Tibia } & \multicolumn{3}{|c|}{ Femora } & \multirow{2}{*}{ Bt III } & \multirow{2}{*}{$\begin{array}{c}\text { FW } \\
\text { L }\end{array}$} \\
\hline & & $\mathrm{L}$ & $\mathrm{W}$ & $\mathrm{L}$ & $\mathrm{W}$ & $\mathrm{H}$ & I & II & III & $\mathrm{I}$ & II & III & & \\
\hline$\widehat{~ H o l o t y p e}$ & 9.5 & 1.6 & 3.1 & 2.8 & 1.7 & 1.8 & 2.7 & 2.7 & 4.2 & 2.5 & 2.6 & 6.7 & 1.8 & 5.2 \\
\hline
\end{tabular}

Allotype. Female. Same as holotype, MNHN (MNHNENSIF2057).

Description. Similar to C. aptera n. sp., but size smaller; hindlegs shorter; coloration darker; a spine is also intercalated between outer subapical spurs 1 and 2 of tibia III (in addition to the spine intercalated between outer subapical spurs 2 and 3; fig. 26).

Male. Male genitalia. Slightly different from those of C. aptera n.sp.: pseudepiphallus with obtuse apex; pseudepiphallic parameres less elongated (figs. 36, 37).

Female. Apart from the above-mentioned non sexual characters, similar to $C$. aptera n. sp. female.

In most crickets, the character differences between C. aptera and C. crypta are strong enough to distinguish two species. I therefore tentatively consider them as distinct species, but additional specimens would be required to confirm this hypothesis.

Biology. The male holotype and female allotype have been found by night staying on Pandanus sp. leaves.

\section{Creolandreva chaloupensis $\mathbf{n}$. sp. (figs. 27-29, 30-32; tab. 4)}

Holotype. Male. Indian Ocean, Mascarene archipelago, Réunion island, Ravine de la Grande Chaloupe. Alt. $555 \mathrm{~m}$, 205' $47^{\prime \prime}$ S, 55²3"20'E; 20.IV.2007. S. Hugel. MNHN (MNHN-ENSIF2058).

Description. Head. Rostrum in dorsal view 0.23 times as wide as the head (fig. 28); rostrum concave in dorsal view, with rostrum sides markedly protruding in side view (fig. 27); frons concave in side view. Antenna $>9.5 \mathrm{~mm}$ long. Maxillary palpi $3^{\text {rd }}$ article 1.1 times as long as the $4^{\text {th }} ; 4^{\text {th }}$ slightly widened apically; $4^{\text {th }} 0.8$ times as long as the $5^{\text {th }} ; 5^{\text {th }} 1.7$ times as long as wide subapically (fig. 27). Thorax. Pronotum 1.6 times as wide as long in dorsal view; lateral lobe posterior angle slightly arched towards the insect axis.

Legs. Tibia I with oval inner tympanum and without outer tympanum. Tibia III (fig. 29) 0.7 times as long as femur III; with 11 dorsal spines above the inner subapical spurs; with 810 dorsal spines above outer subapical spurs. Hindbasitarsus with 7 dorsal spines on the outer carina and 5-6 spines on the inner carina; with one long apical spur on each side (fig. 29). Cerci $>5 \mathrm{~mm}$ long. Color. General coloration yellowish-grey with darker spots. Face and rostrum shiny black. Tibiae I, II, III and hind basitarsus with dark bands. Femora III with fine outer stripes. Fore wings with dark veins and transparent cells; dorsum of abdomen black. Male Wings. Tegmina covering almost the abdomen, reaching the posterior margin of epiproct and reaching the middle of hind femora; dorsal field with 5 longitudinal veins, with transverse veins (fig. 28); lateral field with 5 longitudinal veins, with few transverse veins (fig. 27).
Hindwings present, distinctly longer than the tegmina, apex truncated.

Genitalia (fig. 30-32). With a V-shaped posterior notch in dorsal view; with two tiny paired process on the basis of the notch. Pseudepiphallic parameres strongly sclerotized; each with a tooth-like ventral lobe pointing outwards; with fenestrations in ventral view.

Female. Unknown.

Biology. The single Creolandreva chaloupensis n. g., n. sp. specimen has been collected on the basis of a dead trunk at $2.00 \mathrm{am}$. This species was absent from the mass-collects conducted by the Insectarium de la Réunion team in the type locality, despite a careful investigation by various techniques, suggesting the scarcity of this species and/or a peculiar ecological niche. C. cocottensis n. sp., a similar species from la Réunion occurs in endemic Syzygium sp. trunks; suggesting that C. Chaloupensis n. sp. might be looked for in trunks of the same genus in la Grande Chaloupe.

\section{Creolandreva crepitans $\mathbf{n} . \mathbf{s p}$. (figs. 38-45, 56-58; tab. 5)}

Holotype. Male. Indian Ocean, Mascarene archipelago, Mauritius, Savanne District, Black River National Park, Plaine Champagne; $680 \mathrm{~m}$ alt.; $20^{\circ} 25^{\prime} 19^{\prime \prime}$ S 57²6’28”E; 19.II.2008. S. Hugel, MNHN (MNHN-ENSIF2059).

Allotype. Female. Same as holotype, MNHN (MNHNENSIF2060).

Paratypes. Male. 1ठ, Mauritius, Plaine Wilhelms District, Black River National Park, Macchabee viewpoint; 589 m alt.; $20^{\circ} 23^{\prime} 36^{\prime \prime}$ S 57 $26^{\prime} 26^{\prime \prime E}$; 25.II.2008. S. Hugel leg. and coll.. Females. 1 , same as holotype; 19.II.2008. S. Hugel leg. and coll.. 1 , same as male paratype; 25.II.2008. S. Hugel leg. and coll.. 19 Mauritius, Plaine Wilhelms District, Black River National Park, viewpoint near UNESCO plot, $660 \mathrm{~m}$ alt.; $20^{\circ} 24^{\prime} 06^{\prime} S$ 57²7’34”E; 24.II.2008. S. Hugel leg., CIRAD Réunion. 29 , Mauritius, Plaine Wilhelms District, Black River National Park, Florin, $610 \mathrm{~m}$ alt.; 20²3'28"S 57²7'38”E; 25.II.2008. S. Hugel leg., MSIRI, S. Hugel coll..

Description. Head. Rostrum apex inconspicuously convex in dorsal view, with a small concavity in the middle (fig. 39); rostrum distinctly protruding in side view; rostrum $0.28-0.29$ times as wide as the head; frons concave in side view. Antenna $>23 \mathrm{~mm}$ long. Thorax. Pronotum 1.47-1.70 times as wide as long in dorsal view (holotype: 1.62; allotype: 1.48).

Legs. Tibia I with inner and outer tympana. Tibia III 0.570.61 times as long as femur III (holotype: 0.62; allotype: 0.61); with 5-9 dorsal spines above the inner subapical spurs; with 6-12 dorsal spines above outer subapical spurs. Hindbasitarsus 


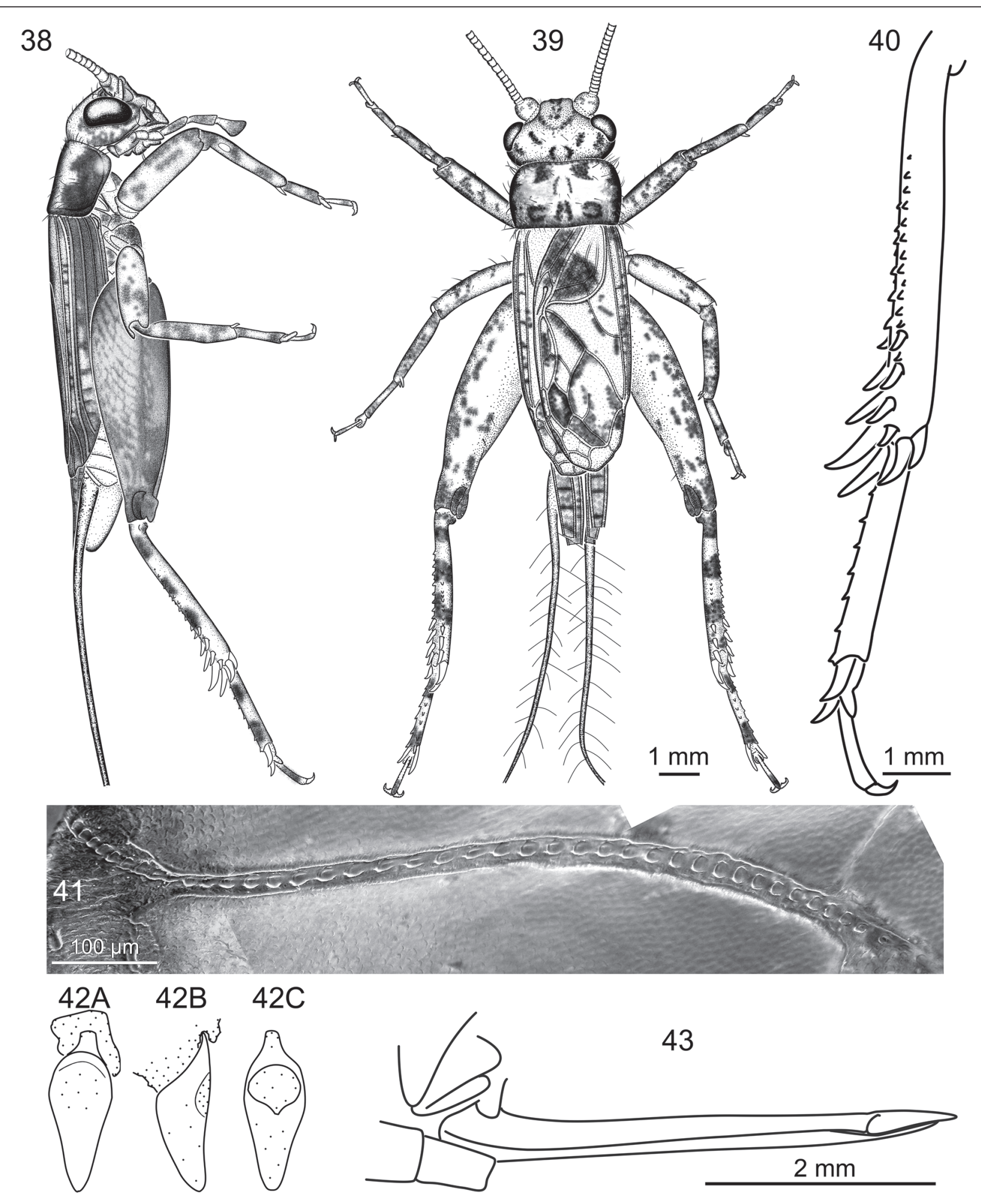

Figure 38-43

Creolandreva crepitans n. g., n. sp. 38-41, male paratype. 38, lateral habitus. 39, dorsal habitus. 40, external lateral view of tibia and tarsus III. 41, scan electron microscope view of the stridulatory file. 42-43 female allotype. 42, copulatory papilla in dorsal (A), lateral (B) and ventral (C) views. 43, ovipositor in lateral view. 
$44 \mathrm{~A}$

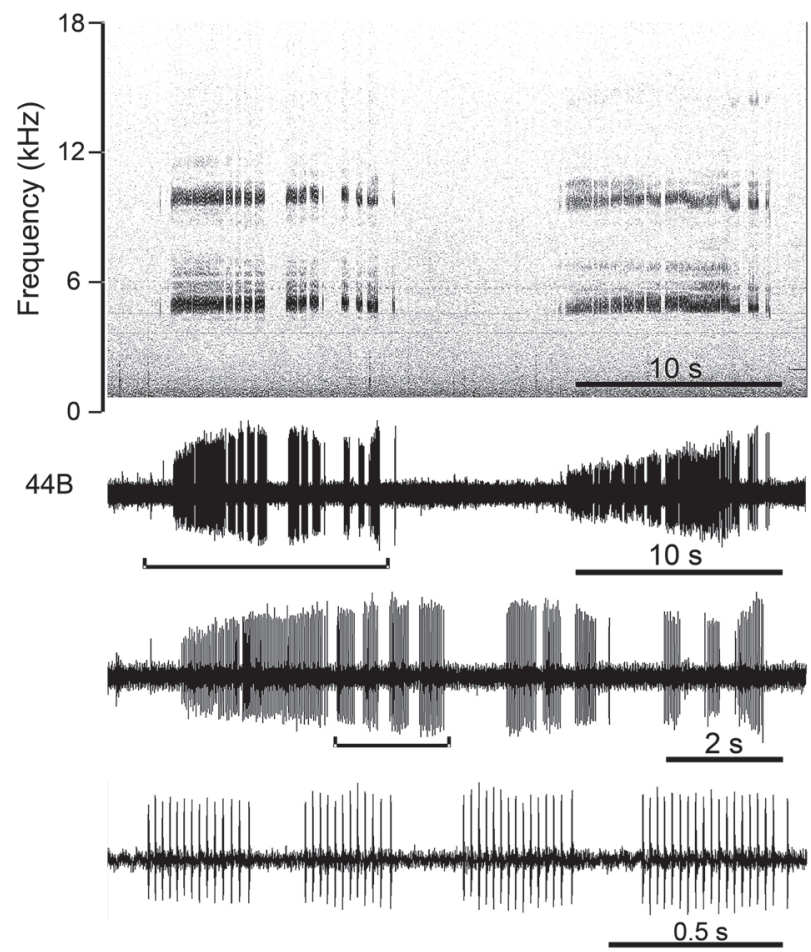

$45 \mathrm{~A}$
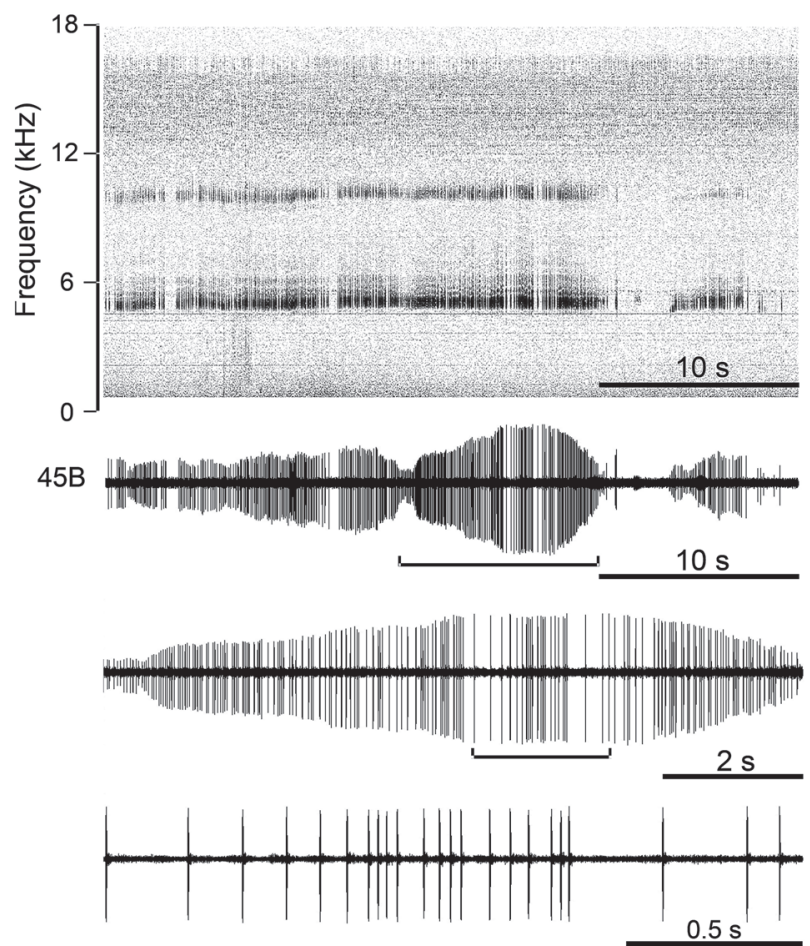

Figure 44-45

Creolandreva crepitans n. g., n. sp. stridulation (A) spectrogram (B) oscillogram. 44, male holotype, calling song, studio in natura, $25^{\circ} \mathrm{C}, 1 \mathrm{~h} 00$ am. 45 , male paratype, courtship song, in natura, $25^{\circ} \mathrm{C}, 3 \mathrm{~h} 00 \mathrm{am}$.

with 6-8 dorsal spines on the outer carina and 4-7 spines on the inner carina; with one long apical spur on each side (fig. 40). Wings. Tegmina well developed, hindwings longer than tegmina (fig. 39). Cerci $\sim 8 \mathrm{~mm}$ long. Color. General coloration yellowish-grey with darker spots. Pronotum lateral lobes dark brown. Tibiae I, II, III and hind basitarsus with dark bands. Femora III with fine outer stripes. Tegmina lateral field dark brown on the basis; lateral field veins dark brown distally.

Male. Head. Maxillary palpi $3^{\text {rd }}$ article 1.04 times as long as the $4^{\text {th }} ; 4^{\text {th }} 0.77-0.83$ times as long as the $5^{\text {th }}, 1.63-1.71$ times as long as wide subapically. Wings. Tegmina with stridulating devices; file (A1) straight (without distinct bend) between the two major bends; file with $\sim 42$ teeth; with $1-2$ harp veins; with a distinct mirror without crossing vein. Apical field short, with few, large cells. Hindwings longer than forewings; reaching the hind knees. Genitalia (fig. 56-58). Pseudepiphallic sclerite elongated, longer than wider; with a deep and wide posterior median notch dividing the pseudepiphallus in two posterior lobes; with two weakly sclerotized mediodorsal digitiform lobes directed upwards. Pseudepiphallic parameres with 2 posterior lobes each; antero median part of pseudepiphallic parameres surrounding a circular sclerification. Color. Tegmina with basal area dark brown, diagonal and veins in the chordal and mirror area surrounded by dark brown patches. Hindwings with transverse veins surrounded by dark brown patches.

Female. Head. 0.28-0.29 times as wide as the head (allotype:

Table 5. Measurements ( $\mathrm{mm}$ ) of Creolandreva crepitans n. g., n. sp.

\begin{tabular}{|c|c|c|c|c|c|c|c|c|c|c|c|c|c|c|c|}
\hline & \multirow{2}{*}{$\begin{array}{c}\text { Body } \\
\text { L }\end{array}$} & \multicolumn{2}{|c|}{ Head } & \multicolumn{3}{|c|}{ Thorax } & \multicolumn{3}{|c|}{ Tibia } & \multicolumn{3}{|c|}{ Femora } & \multirow{2}{*}{ Bt III } & \multirow{2}{*}{$\begin{array}{c}\mathrm{FW} \\
\mathrm{L}\end{array}$} & \multirow{2}{*}{$\begin{array}{l}0 \\
\mathrm{~L}\end{array}$} \\
\hline & & $\mathrm{L}$ & $\mathrm{W}$ & $\mathrm{L}$ & $\mathrm{W}$ & $\mathrm{H}$ & I & II & III & I & II & III & & & \\
\hline$\delta$ Holotype & 8.7 & 1.8 & 2.4 & 1.6 & 2.5 & 1.2 & 2.3 & 2.5 & 3.6 & 2.3 & 2.3 & 5.8 & 1.9 & 6.1 & - \\
\hline I Allotype & 7.9 & 1.7 & 2.9 & 1.8 & 2.6 & 1.5 & 2.2 & 2.3 & 3.5 & 2.2 & 2.3 & 5.8 & 1.8 & 6.1 & 3.8 \\
\hline$\delta$ Paratype & 9.2 & 1.6 & 2.6 & 1.5 & 2.4 & 1.2 & 2.1 & 2.3 & 3.5 & 2.1 & 2.2 & 5.7 & 1.6 & 5.7 & - \\
\hline \multirow{3}{*}{$\begin{array}{r}\text { o }(\mathrm{n}=6) \min \\
\max \\
\text { average }\end{array}$} & 7.9 & 1.6 & 2.5 & 1.5 & 2.4 & 1.2 & 1.9 & 2.1 & 3.2 & 2.2 & 2.2 & 5.2 & 1.6 & 5.2 & 3.6 \\
\hline & 10.3 & 1.8 & 2.9 & 1.8 & 2.7 & 1.5 & 2.2 & 2.4 & 3.6 & 2.3 & 2.3 & 5.8 & 1.8 & 6.1 & 3.9 \\
\hline & 9.0 & 1.7 & 2.7 & 1.7 & 2.6 & 1.3 & 2.1 & 2.2 & 3.4 & 2.2 & 2.3 & 5.6 & 1.7 & 5.8 & 3.8 \\
\hline
\end{tabular}



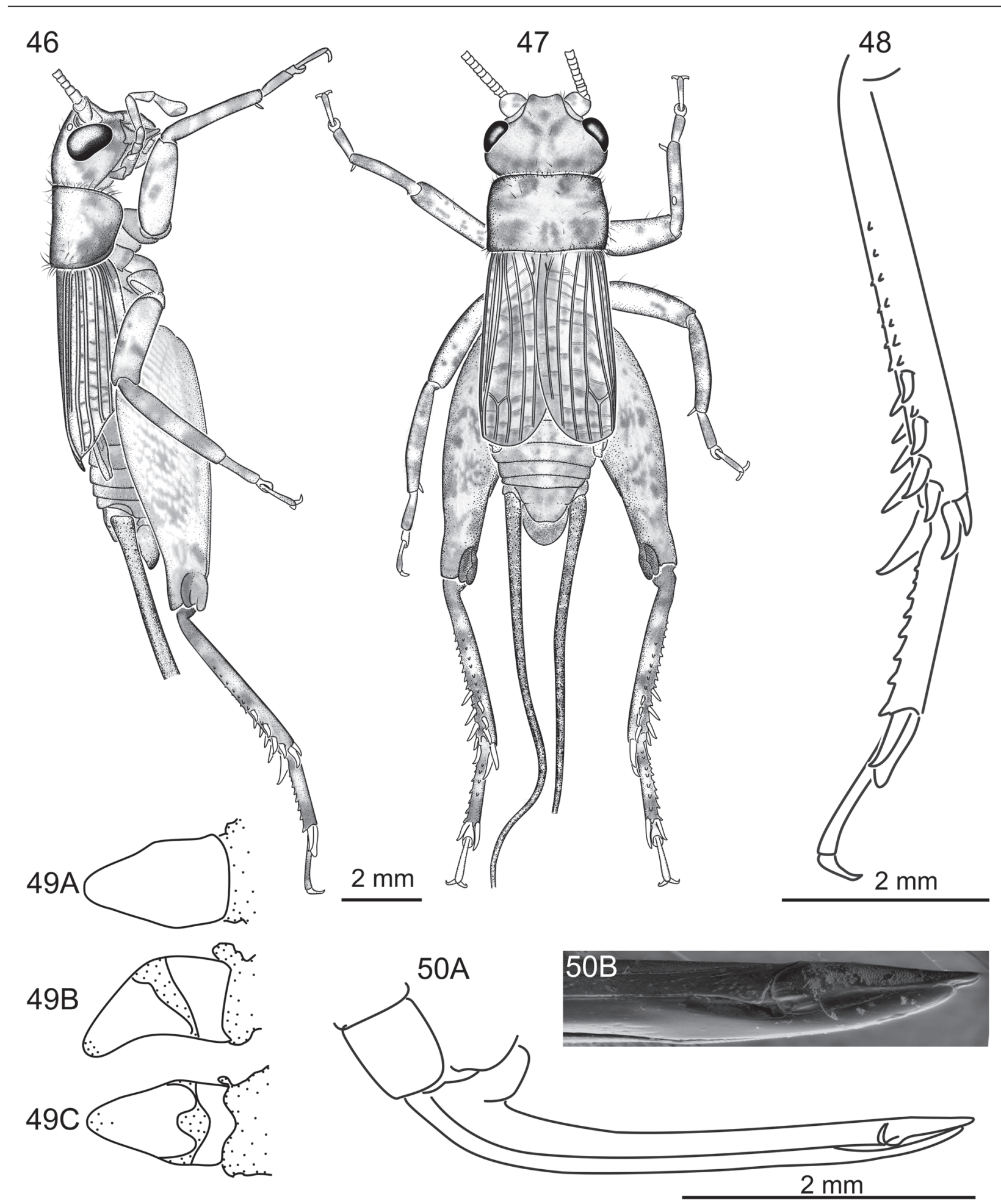

Figure 46-50

Creolandreva cocottensis n. g., n. sp. 46-48, male holotype. 46, lateral habitus. 47, dorsal habitus. 48, external lateral view of tibia and tarsus III. 49-50, female allotype. 49, copulatory papilla in dorsal (A), lateral (B) and ventral (C) views. 50, ovipositor in lateral view (A) scan electron microscope lateral view of ovipositor tip (B). 


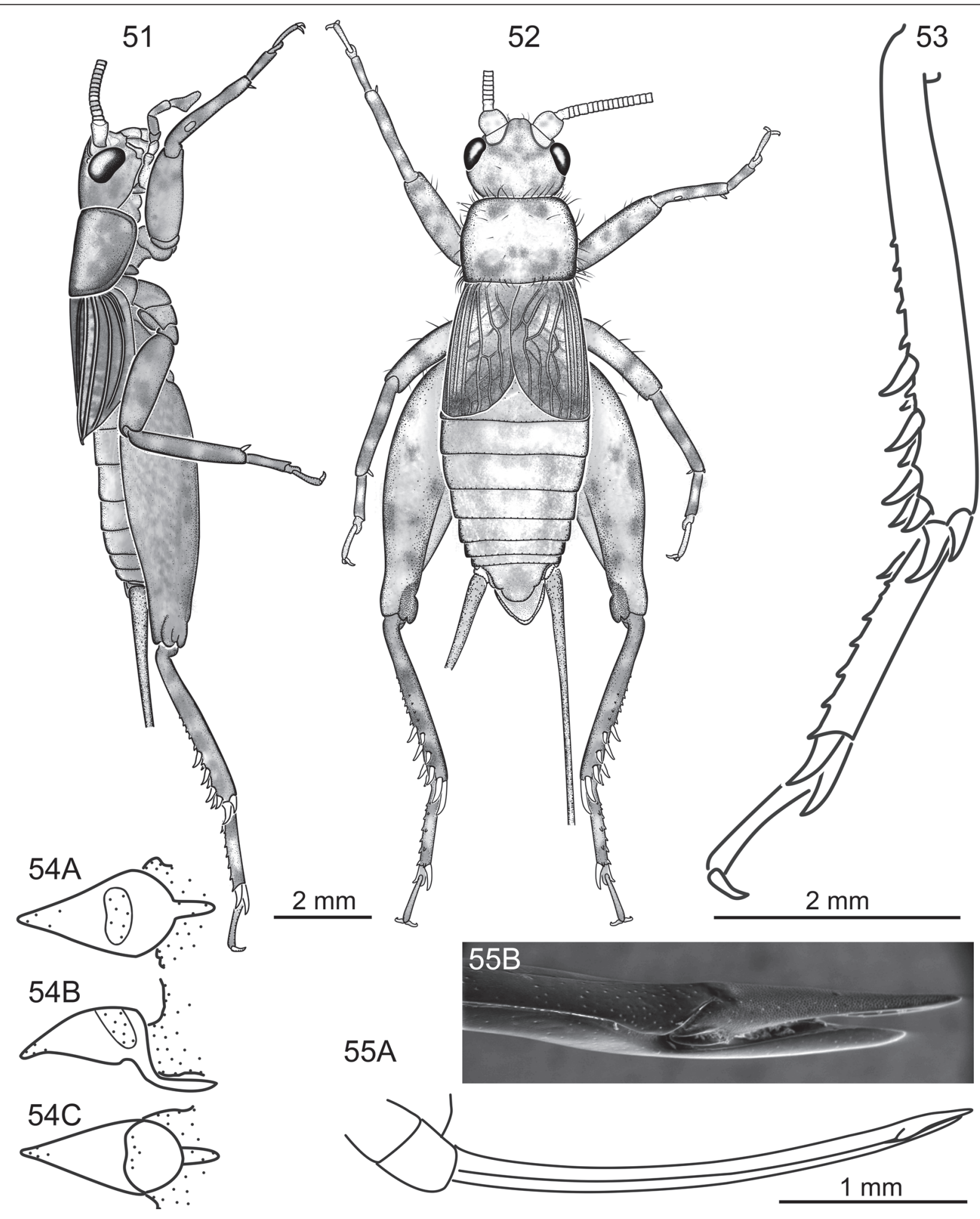

Figure 51-55

Creolandreva brachyptera n. g., n. sp. 51-53, male holotype. 51, lateral habitus. 52, dorsal habitus. 53, external lateral view of tibia and tarsus III. 54-55, female allotype. 54, copulatory papilla in dorsal (A), lateral (B) and ventral (C) views. 55, ovipositor in lateral view (A) scan electron microscope lateral view of ovipositor tip (B). 

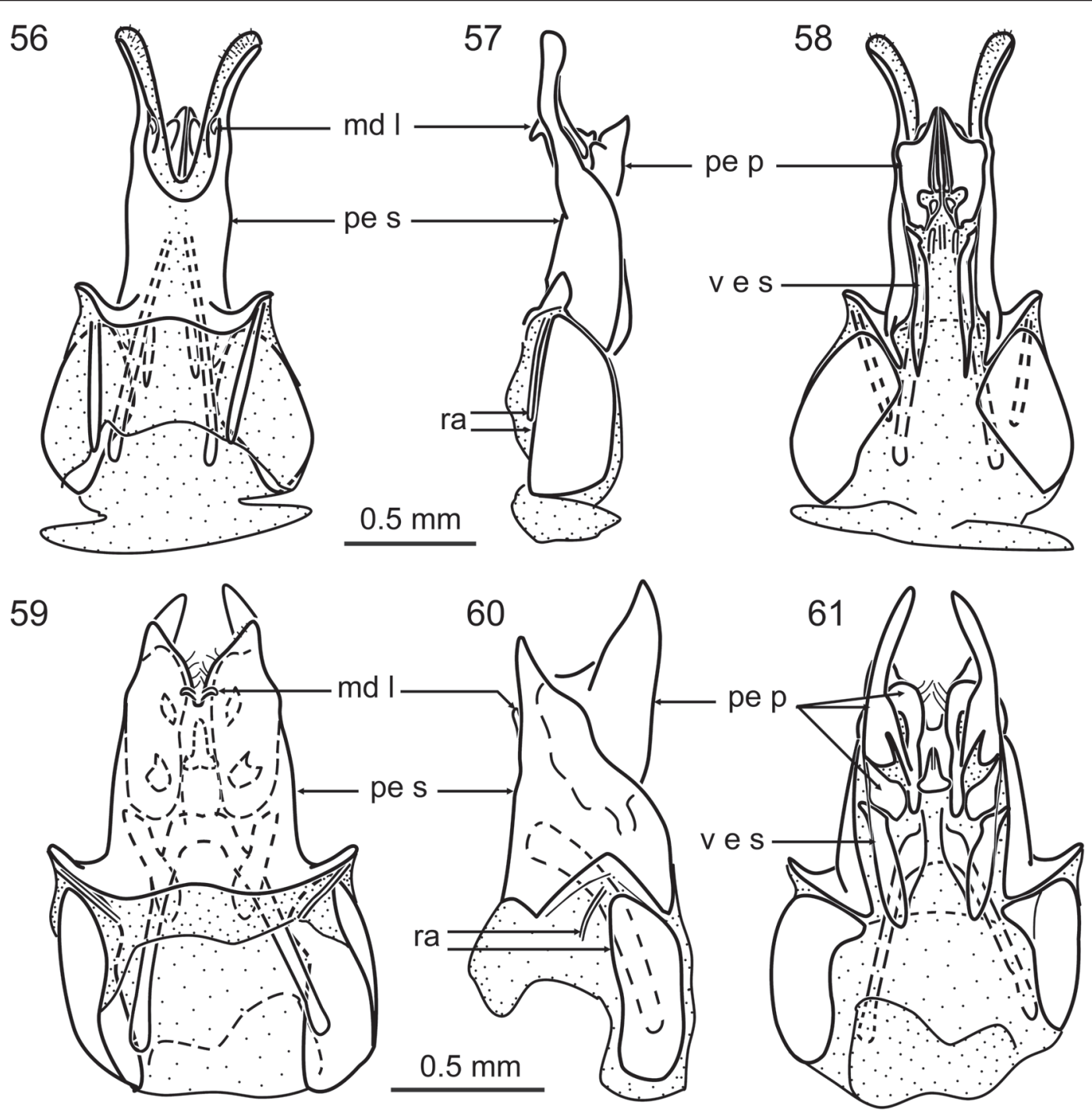

62

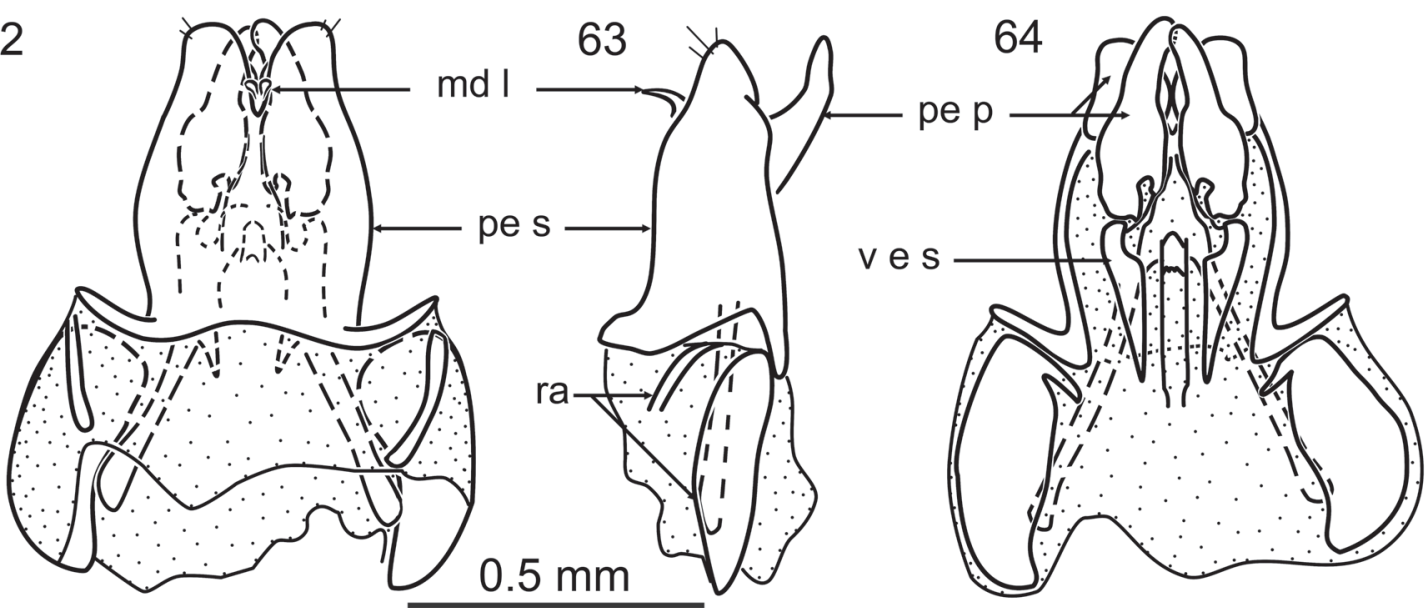

Figure 56-64

Male genitalia of Creolandreva n. g. species from Mauritius in dorsal $(56,59,62)$ lateral $(57,60,63)$ and ventral $(58,61,64)$ views. 56-58, C. crepitans $\mathbf{n}$. sp. male holotype. 59-61, C. cocottensis n. sp. male holotype. 62-64, C. brachyptera $\mathbf{n}$. sp. male holotype. Abbreviations: see material and methods. 
0.29). Maxillary palpi $3^{\text {rd }}$ article $0.90-1.07$ times as long as the $4^{\text {th }}$ (allotype: 1.07$) ; 5^{\text {th }} 0.75-0.83$ times as long as the $4^{\text {th }}$ (allotype: 0.83), 1.7-2.0 times as long as wide subapically (allotype: 1.7). Wings. With 5-6 longitudinal veins in the dorsal field; with 6-7 veins in the lateral field; with numerous transverse veinlets. Abdomen. Subgenital plate without emargination. Cerci as in $\hat{0},>7 \mathrm{~mm}$. Ovipositor with an angle at the basis; strait after the basis; not widened in ventral view, apex slightly widened in side view (fig. 43); dorsal and ventral valves immovably connected to each other ; right and left valves not immovably connected; apex of dorsal valves with a longitudinal discontinuity on its outer side (fig. 43); tip of dorsal valves pointed; ventral valves without transversal preapical notch in the ventral margin (fig. 43). Copulatory papilla. Bilaterally subsymmetrical in dorsal view (fig. 42), with an anterior protrusion forming an anterior ventral plate. Color. Tegmina darkened around transverse veinlets and in the basal area.

Bioacoustics. The small confined cavities where Creolandreva crepitans n. sp. is living (not only as a refuge, but also during activity) are not allowing the males to lift the hindwings sufficiently for stridulation. Therefore, both song production and mating are taking place late at night outside the cavities, directly on the trunk surface, whether most of the other activities seem mostly localized within the cavities. The calling song is produced by the male while walking on the tree trunk surface and exploring the natural cavities entrances (see biology below). When the male contacts a female on a cavity entrance, it turns around it while producing a courtship song similar to the calling song, but more continuous (fig. 45 , in natura). During mating, similar syllables are produced (data not shown). The calling song of Creolandreva crepitans n. sp. (fig. 44, studio in natura) consists of irregularly repeated echemes (every 0.450 to $9.534 \mathrm{~s}$; average \pm sd: $1.436 \pm 1.992 \mathrm{~s}$ at $25^{\circ} \mathrm{C}, 2$ specimens) of various lengths (from 0.258 to $2.913 \mathrm{~s}$; average \pm sd: $702 \pm 611$ $\mathrm{ms}$, at $25^{\circ} \mathrm{C}, 2$ specimens) and separated by silences of various lengths (from 0.072 to $9.103 \mathrm{~s}$; average \pm sd: $744 \pm 1965 \mathrm{~ms}$, at $25^{\circ} \mathrm{C}, 2$ specimens). Syllables are regularly repeated at a rate of 43 to $48 \mathrm{~Hz}$ (average \pm sd: $46 \pm 2 \mathrm{~Hz}$ at $25^{\circ} \mathrm{C}$ ). The dominant frequency ranges from 4.96 to $5.08 \mathrm{kHz}$; the 2nd harmonic amplitude, peaking at $9.80-10.01 \mathrm{kHz}$, represents $55-70 \%$ of the dominant frequency peak amplitude.

Biology. This species seems the most widespread Landrevinae in Mauritius. It has been found in four localities ranging from 580 to 680 meters in altitude. As the other Landrevinae species from Mauritius, Creolandreva crepitans n. sp. is strictly associated with endemic trees, living within natural cavities on dead Sapotaceae branches from living trees (Sideroxylon sp., Labourdonnaisia sp.) from near the ground up to $\sim 3 \mathrm{~m}$ from the ground level. In addition, this species occurs also under barks of large Sapotaceae trunks (Labourdonnaisia sp., at $1 \mathrm{~m}$ from the ground) and under barks and/or within lichens of Melastomataceae (Warneckea trinervis, on the highest branches at -4 $\mathrm{m}$ from the ground). Each time, several specimens at various stages of development have been found together within the same branch, but only few trees in each locality were lodging the species. Every stage of development has been observed in all localities, suggesting the presence of adults throughout the year.

\section{Creolandreva cocottensis n. sp. (figs. 46-50, 59-61; tab. 6)}

Holotype. Male. Indian Ocean, Mascarene archipelago, Mauritius, Savanne District, Black River National Park, Montagne Cocotte; $745 \mathrm{~m}$ alt.; 20²6'29"S 57²8'20"E; 25.II.2008, ab larva. S. Hugel, MNHN (MNHNENSIF2061).

Allotype. Female. Same as holotype, MNHN (MNHNENSIF2062).

Paratype. Female. $1 \propto$, same as holotype, ab larva; S. Hugel leg. and coll..

Description. Head. Rostrum in dorsal view 0.26 times as wide as the head (fig. 46); rostrum concave in dorsal view, with rostrum sides markedly protruding in side view (fig. 47); frons concave in side view. Antenna $>33 \mathrm{~mm}$ long. Thorax. Pronotum 1.5 times as wide as long in dorsal view; lateral lobe posterior angle slightly folded towards the insect axis.

Legs. Tibia I with oval inner tympanum and without outer tympanum. Tibia III (fig. 48) 0.6-0.7 times as long as femur III; with 5-9 dorsal spines above the inner subapical spurs; with 8-12 dorsal spines above outer subapical spurs. Hindbasitarsus with 6-8 dorsal spines on the outer carina and 4-7 spines on the inner carina; with one long apical spur on each side (fig. 48). Cerci $>9 \mathrm{~mm}$ long. Color. General coloration yellowishgrey with darker spots. Pronotum lateral lobes dark except the anterior ventral edge. Tibiae I, II, III and hind basitarsus with dark bands. Femora III with fine outer stripes. Fore wings with veins surrounded by dark areas.

Wings. Similar in both genders; tegmina covering almost the abdomen, reaching the middle of hind femora; with 5 longitudinal veins in the dorsal field; with transverse veins (fig. 47). Hindwings present, distinctly longer than the tegmina.

Male. Only the holotype is known. Head. Maxillary palpi $3^{\text {rd }}$ article 0.97 times as long as the $4^{\text {th }} ; 5^{\text {th }} 0.9$ times as long as the $4^{\text {th }}, 1.6$ times as long as wide subapically (fig. 46). Genitalia (fig. 59-61). With a V-shaped posterior notch in dorsal view; with two tiny paired process on the basis of the notch. Pseudepiphallic parameres strongly sclerotized; each with a tooth-like ventral lobe pointing the median plan; with fenestrations in ventral view.

Table 6. Measurements ( $\mathrm{mm}$ ) of Creolandreva cocottensis $\mathbf{n} . \mathbf{g . ,} \mathbf{n}$. sp.

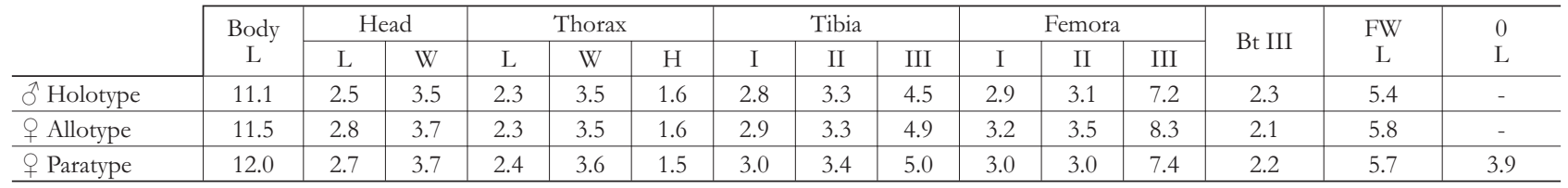


Female. Head. Maxillary palpi $3^{\text {rd }}$ article $0.96-1.00$ times as long as the $4^{\text {th }}$ (allotype: 1.00); $5^{\text {th }} 0.85$ times as long as the $4^{\text {th }}, 1.4-1.5$ times as long as wide subapically (allotype: 1.5 ). Subgenital plate without emargination. Cerci as in $\widehat{T}$ holotype, $>9 \mathrm{~mm}$. Ovipositor curved on the basis, strait after the basis, not widened in ventral view, apex inconspicuously widened in side view (fig. 50); dorsal and ventral valves immovably connected to each other; right and left valves not immovably connected; apex of dorsal valves with a longitudinal discontinuity on its outer side (fig. 50); tip of dorsal valves pointed; ventral valves without transversal preapical notch in the ventral margin (fig. 50). Copulatory papilla. Bilaterally subsymmetrical in dorsal view (fig. 49), without anterior protrusion.

One juvenile male collected in the view point on Rivière Noire of Plaine Champagne (681 m alt.; 20 25’39S 057 $25^{\prime} 43 \mathrm{E}$; 22.III.2005; S. Hugel leg. and coll.) on Warneckea trinervis might belong to this species.

Biology. I found all the three specimens of this species on a dead section of a particularly large endemic Syzygium sp. trunk (at $2 \mathrm{~m}$ from the ground level), and failed to found additional specimens on the few similar trunks of the locality. In this trunk, specimens of $C$. cocottensis n. sp. where together with adults $C$. brachyptera n. sp.

\section{Creolandreva brachyptera n. sp. (figs. 51-55, 62-64; tab. 7)}

Holotype. Male. Indian Ocean, Mascarene archipelago, Mauritius, Savanne District, Black River National Park, Montagne Cocotte; 735-745 m alt.; 2026'28-29”S 57²8'2023"E; 6.III.2008; S. Hugel, MNHN (MNHN-ENSIF2063).

Allotype. Female. Same as holotype, MNHN (MNHNENSIF2064).

Paratypes. Paratype localities same as holotype. Males. 10 , 23.II.2008; S. Hugel leg. and coll.. 1ठ̂, 25.II.2008; S. Hugel, MSIRI. Females. 19, 23.II.2008; S. Hugel leg. and coll.. 1, 25.II.2008; S. Hugel, MSIRI. 1은. 6.III.2008; S. Hugel, CIRAD Réunion.

Description. Head. Rostrum narrow; apex convex in dorsal view (fig. 52), only slightly protruding in side view; frons convex in side view. Antenna $>25 \mathrm{~mm}$ long. Thorax. Pronotum 1.32-1.40 times as wide as long in dorsal view (holotype: 1.40; allotype: 1.33$)$.
Legs. Tibia I with inner and outer tympanum. Tibia III 0.60.7 times as long as femur III; with 2-6 dorsal spines above the inner subapical spurs; with 6-9 dorsal spines above outer subapical spurs.

Hindbasitarsus with 6-8 dorsal spines on the outer carina and 4-5 spines on the inner carina; with one long apical spur on each side (fig. 53). Wings. Similar in both genders. Tegmina without any stridulatory device; short, 1.4-1.7 times longer than pronotum; with 5-6 longitudinal veins in the dorsal field; with few transverse veins. Hindwings present, entirely covered by the forewings. Cerci $>9$ mm long. Color. General coloration grey-blackish with lighter spots. Tegmina lateral field dark brown; dorsal field with dark spots. Tibiae I, II, III and hind basitarsus yellowish-grey with dark bands. Femora III with fine outer stripes.

Male. Head. 0.21-0.25 times as wide as the head (holotype: $0.25)$. Maxillary palpi $3^{\text {rd }}$ article $0.90-1.00$ times as long as the $4^{\text {th }}$ (holotype: 0.90$) ; 5^{\text {th }} 0.76-0.91$ times as long as the $4^{\text {th }}$ (holotype: 0.83), 1.1-1.3 times as long as wide subapically (holotype: 1.3). Genitalia (fig. 62-64). Pseudepiphallic sclerite with a posterior median notch; with two long, weakly sclerotized mediodorsal digitations directed upwards. Antero median part of pseudepiphallic parameres surrounding a circular sclerification.

Female. Head. Rostrum 0.18-0.23 times as wide as the head (allotype: 0.23 ). Maxillary palpi $3^{\text {rd }}$ article $0.96-1.16$ times as long as the $4^{\text {th }}$ (allotype: 1.02 ); $5^{\text {th }} 0.67-0.71$ times as long as the $4^{\text {th }}$ (allotype: 0.69), 1.3-1.4 times as long as wide subapically (allotype: 1.4). Abdomen Subgenital plate without emargination. Cerci as in $\hat{\sigma},>9 \mathrm{~mm}$. Ovipositor slightly and regularly curved upwards, not widened in ventral view, apex slightly widened in side view (fig. 55); apex of dorsal valves with a longitudinal discontinuity on its outer side (fig. 55); tip of dorsal valves pointed; ventral valves without transversal preapical notch in the ventral margin (fig. 55). Copulatory papilla. Bilaterally subsymmetrical in dorsal view (fig. 54), with an anterior protrusion forming an anterior ventral process.

Biology. C. brachyptera n. sp. occurs in natural cavities of dead branches/trunks from living endemic Myrtaceae (Syzygium sp.), and within plant material covering these trees. Is has been found near the ground $(\sim 50 \mathrm{~cm})$ to high dead branches $(4 \mathrm{~m})$.

Table 7. Measurements ( $\mathrm{mm})$ of Creolandreva brachyptera $\mathbf{n}$. g., n. sp.

\begin{tabular}{|c|c|c|c|c|c|c|c|c|c|c|c|c|c|c|c|}
\hline & \multirow{2}{*}{$\begin{array}{c}\text { Body } \\
\text { L }\end{array}$} & \multicolumn{2}{|c|}{ Head } & \multicolumn{3}{|c|}{ Thorax } & \multicolumn{3}{|c|}{ Tibia } & \multicolumn{3}{|c|}{ Femora } & \multirow{2}{*}{ Bt III } & \multirow{2}{*}{$\begin{array}{c}\mathrm{FW} \\
\mathrm{L}\end{array}$} & \multirow{2}{*}{$\begin{array}{l}0 \\
\mathrm{~L}\end{array}$} \\
\hline & & $\mathrm{L}$ & $\mathrm{W}$ & $\mathrm{L}$ & $\mathrm{W}$ & $\mathrm{H}$ & I & II & III & I & II & III & & & \\
\hline$\widehat{~}$ Holotype & 10.3 & 1.9 & 2.4 & 1.8 & 2.6 & 1.3 & 2.3 & 2.8 & 4.0 & 2.5 & 2.7 & 6.3 & 1.9 & 3.1 & - \\
\hline Q Allotype & 10.0 & 2.1 & 2.5 & 2.2 & 2.9 & 1.3 & 2.5 & 3.0 & 4.5 & 2.5 & 2.7 & 7.0 & 2.1 & 3.0 & 5.4 \\
\hline$\widehat{o}(\mathrm{n}=3) \min$ & 10.3 & 1.7 & 2.3 & 1.8 & 2.4 & 1.1 & 2.3 & 2.5 & 3.9 & 2.4 & 2.5 & 6.0 & 1.9 & 2.8 & - \\
\hline $\max$ & 10.7 & 2.1 & 2.5 & 1.9 & 2.7 & 1.3 & 2.3 & 2.8 & 4.2 & 2.6 & 2.7 & 6.3 & 2.0 & 3.2 & - \\
\hline average & 10.4 & 1.9 & 2.4 & 1.9 & 2.6 & 1.3 & 2.3 & 2.6 & 4.0 & 2.5 & 2.6 & 6.2 & 2.0 & 3.0 & - \\
\hline$q(\mathrm{n}=4) \mathrm{min}$ & 10.0 & 1.9 & 2.5 & 2.2 & 2.9 & 1.2 & 2.5 & 3.0 & 4.4 & 2.5 & 2.7 & 7.0 & 2.1 & 3.0 & 5.3 \\
\hline $\max$ & 12.1 & 2.1 & 2.7 & 2.2 & 3.0 & 1.5 & 2.7 & 3.1 & 4.5 & 2.8 & 2.8 & 7.3 & 2.1 & 3.5 & 5.7 \\
\hline average & 10.9 & 2.0 & 2.6 & 2.2 & 3.0 & 1.3 & 2.6 & 3.0 & 4.5 & 2.7 & 2.7 & 7.1 & 2.1 & 3.2 & 5.5 \\
\hline
\end{tabular}




\section{Discussion}

\section{Landrevinae of Africa and south western Indian Ocean islands}

Only nine Landrevinae species are known occurring outside the Indo-Australian area: Oreolandreva brevipennis Chopard 1945 from mainland Western Africa (Cameroun), Microlandreva notabilis Chopard 1958 from Comoros and the seven above-described species from Réunion and Mauritius.

Males of these nine species share with some western Pacific Landrevinae reviewed by Otte (1988, as Landrevini) the pseudepiphallic sclerite widened and back-curved anteriorly. They are however clearly distinct by the particularly extended ventral ectophallic sclerites connected to ectophallic apodemes near the arch, and articulated with anterior part of pseudepiphallic parameres.

Oreolandreva shares with Microlandreva the pseudepiphallic sclerite containing two sclerites articulated dorsomedially, but differs from Microlandreva and Creolandreva n. g. by: - the lack of hindwings (in Microlandreva and Creolandreva n. g. hindwings are always present when forewings are present); - the male dorsal glands on metanotum forming 2 pits rimmed by setae (dorsal glands are absent in Creolandreva n. g. and are forming foldlike transverse elevations in Microlandreva); - the bristles on the dorsum of the head (only few small bristles are occurring on the sides of the rostrum in Microlandreva and Creolandreva); - the number of spines on the inner side of hind basitarsus (1-2 in Oreolandreva; 4-7 in Microlandreva and Creolandreva n. g.); - the rami with one distinct sclerite (two distinct sclerites in Microlandreva and Creolandreva n. g.: an elongated dorsal one and an ovoid lateral one; the rami sclerites have obviously been damaged in $M$. notabilis holotype)

Without a cladistic analysis of the family, it is therefore difficult to clarify the exact status of the only cricket considered as a Landrevinae from mainland Africa relatively to its SWIO islands and Oriental relatives.

Microlandreva and Creolandreva n. g. share the following characters distinguishing them from all other known Landrevinae (data on Oriental species after Otte 1988): - rami with two distinct sclerites: an elongated dorsal one and an ovoid lateral one (the rami sclerites have obviously been damaged in $M$. notabilis holotype and are inconspicuous in $C$. cocottensis n. sp.); - hindwings present when forewings are present (even if when the forewings are reduced); - tibia I and II with 2 apical spurs each (3 on each on Oriental species) - tibia III with 3 inner and 3 outer apical spurs (usually 4 , rarely 3 inner; and 4 outerapicalspurs in Oriental species) - tibia III with 3 inner and 3 outer subapical spurs (usually 4 on each side on Oriental species); - tibia III with a spine between the most proximal outer subapical spurs (nevertheless, this spine is lacking in $M$. notabilis); -1Avein (file;Cu2in Otte(1988)) without distinctbend between the two major bends (unlike Oriental species); - tympanum present in species devoid of FW stridulum (except C. aptera n. sp.; all Oriental mute species are lacking tympana).

Interestingly, whereas external morphology and genital characters are apparently of little use for supra specific classification of Landrevinae (Gorochov \& Warchalowska-Sliwa 2004), they clearly distinguish SWIO islands Landrevinae. It could then be hypothesized that these two genera may constitute a separate clade of Landrevinae, diversified in SWIO. This should be clarified with a cladistic analysis of the whole subfamily. Such an approach is also required to clarify the still discussed position of Landrevinae (Otte 1988; Gorochov 2004).

\section{Generic position of $M$. parvotibialis n. sp.}

Within the Landrevinae, M. parvotibialis n. sp. resembles Apiotarsoides semialatus Chopard 1931. $M$. parvotibialis n. sp. shares with $A$. semialatus the shape of the hindleg with a shortened tibia and elongated hindbasitarsus, and the shortened wings without stridulatory apparatus (Chopard 1931; Otte 1988). However, genitalia of both species are strongly different (one $A$. semialatus paratype dissected; this specimen differs from Otte's illustration by the longer rami relatively to ectophallic apodemes, but interpretation of this assumed difference requires further investigations). Both species are moreover differing by the following characters: the condition of inner tympana on tibia I (absent in A. semialatus); the condition of hindwings (absent in A. semialatus); the ovipositor shape (dorsoventrally compressed in $A$. semialatus); the number of apical spurs on tibia I and II ( 3 apical spurs on each in A. semialatus). The similar general appearance of $M$. parvotibialis n. sp. and A. semialatus could then reveal homoplastic evolution toward a confined habitat.

The genus Microlandreva Chopard 1945 was erected to include a single species from Comoros, $M$. notabilis. M. parvotibialis n. sp. differs from Microlandreva 
original generic description by its size ( 15.9 vs. $5.2 \mathrm{~mm}$ in M. notabilis), the color of its antennae (with black and white stripes in $M$. notabilis) and tympana (absent in M. notabilis). M. parvotibialis n. sp. also differs from M. notabilis by male dorsal glands (abdominal in the former, metathoracic in the latter) and the shape of the hindleg (strongly modified in $M$. parvotibialis $\mathbf{n}$. sp.). All the above mentioned differences are occurring within grylloid genera but (1) genitalia of both species are very similar, (2) despite a localization on different tergites, the dorsal glands of $M$. parvotibialis $\mathbf{n}$. sp. and $M$. notabilis are similar in appearance, forming peculiar successive fold-like transverse elevations, and (3) the ovipositor of both taxa has a transversal preapical notch in the ventral margin of the ventral valves. I therefore propose to keep $M$. parvotibialis $\mathbf{n}$. sp. in the genus Microlandreva at this stage.

\section{Putative apomorphies of Creolandreva n. g.}

In his review of the western Pacific Landrevinae, Otte (1988) attempts to reconstruct a phylogeny of this clade (as Pteroplistinae), and provides a character matrix. There is unfortunately not enough phylogenetical information in the matrix to support most of genera when the distribution data are omitted for the analysis (pers. obs.).

I therefore remain in a taxonomical context to justify Creolandreva n. g. In addition to the distinctive features of Landrevinae of SWIO islands mentioned above, Creolandreva n. g. is characterized by: - the pseudepiphallus comprising one single sclerite with a deep posterior notch; - the paired dorsal median lobes edging the inner side of the pseudepiphallus deep posterior notch; - the ventral ectophallic sclerites moderately extended, only half as long as ectophallic apodemes; - the lack of glandular structures on male metanotum and tergites.

Within Creolandreva n. g., C. chaloupensis n. sp. and $C$. cocottensis $\mathbf{n}$. sp. on the one hand, and C. aptera n. sp., C. crypta n. sp. and C. brachyptera n. sp. on the other hand, are very similar in appearance (head; condition of wings, etc.), and have similar genitalia. Whereas C. crepitans n. sp. genitalia are an elongated and narrowed variant of this latter group, it has a head similar to the former group.

\section{Conservation status of Creolandreva n. gen. species}

All six known Creolandreva n. g. species are endemic to one of the Mascarene islands. Four of them have been found in one single locality, often in one single tree trunk. All the species are occurring in relatively well preserved biota with few exotic plant species, and all are living within dead sections of endemic trees. In Mauritius, most of the tree species lodging Creolandreva n. g. species are considered as vulnerable or endangered (Atkinson and Sevathian 2005). The only Landrevinae known occurring in dry forest is $C$. chaloupensis $\mathbf{n}$. sp. from a critically endangered locality in la Réunion. Ominously, in both Mauritius and la Réunion, we failed to found Creolandreva n. g. species in gardened forest or in plots where the forest has been recently managed (i.e. cleared of exotics), suggesting that the low plant strata (native or mimicked by exotic invasive species) are important for these insect species preservation. For all these raisons, all Creolandreva n. g. species should be considered at least as vulnerable, and some of them as those occurring at very low density only in Montagne Cocotte (Mauritius; C. cocottensis n. sp.) and La Grande Chaloupe (la Réunion; C. chaloupensis n. sp.) might be considered as critically endangered.

\section{Key of Landrevinae from south western Indian Ocean islands (Mauritius, Réunion and Comoros)}

1. Males with dorsal glands forming fold-like transverse elevations covered by the wings (fig. 3, 7); male genitalia with pseudepiphallic sclerite containing two sclerites articulated dorsomedially $(16,19)$, without dorsomedial notch (fig. 15, 18); ovipositor with a preapical notch in the ventral margin of the ventral valves (fig. 4, 11); both sexes winged Microlandreva Chopard 1958. 2

1'. Males without dorsal glands; male genitalia with a simple pseudepiphallic sclerite with a deep posterior notch (fig. 30, 33, 56); ovipositor without preapical notch in the ventral margin of the ventral valves (fig. 50, $55)$; both sexes winged or not. Mascarene archipelago

Creolandreva n. g. 3

2. Body size $<6$ mm. Comoros ...M. notabilis Chopard 1958 .

2'. Body size $>12 \mathrm{~mm}$. Mascarene archipelago

M. parvotibialis n. sp.

3. Tibia I with inner tympanum only; head large, maximal width $>3 \mathrm{~mm}$; rostrum concave in dorsal view; male genitalia with pseudepiphallic parameres exceeding distinctly the posterior tip of pseudepiphallic sclerite (fig. 30, 31, 59, 60)

3'. Tibia I without tympana or with both inner and outer tympanum; head smaller, maximal width $<3 \mathrm{~mm}$; rostrum more or less convex in dorsal view, never concave; male genitalia with pseudepiphallic parameres not overlapping the posterior tip of pseudepiphallic sclerite (fig. 33, 34, 62, 63)

4. Male pseudepiphallic parameres converging (fig. 59, 61). Mauritius ....................................... C. cocottensis n. sp.

4'. Male pseudepiphallic parameres diverging (fig. 30, 32). La Réunion ............................... C. chaloupensis n. sp.

5. Male forewings with stridulatory specializations; female forewings reaching the middle of hind femora; male genitalia elongated, pseudepiphallic sclerite longer than wider (fig. 56); fore tibia with inner and outer tympanum. Mauritius C. crepitans n. sp. 
5'. Apterous or brachypterous, forewings not reaching the middle of hindfemora in both male and female, without stridulatory specializations; male genitalia with pseudepiphallic sclerite wider than long (fig. 59, 62); fore tibia without tympana or with tympana on both sides

6. Brachypterous; with inner and outer tympana. Mauritius .

6' Apterous (vestigial wings covered by the pronotum); without tympana. La Réunion...

7. Tibia III without spine between outer subapical spurs 1 and 2 (but a spine is present between outer subapical spurs 2 and 3; fig. 23); pseudepiphallus with acute apices (fig. 33)

C. aptera n. sp.

7'. Tibia III with a spine between outer subapical spurs 1 and 2 (fig. 26) in addition to the spine intercalated between outer subapical spurs 2 and 3 (the most proximal); pseudepiphallus with obtuse apices (fig. 36).

C. crypta n. sp.

8. Male epiproct wide, rounded (fig. 68); male pseudepiphallic sclerite posterior lobes rounded (fig. 62)

C. brachyptera n. sp.

8' Male epiproct narrower, more squared (fig. 67); male pseudepiphallic sclerite posterior lobes pointing (fig. 65)

C. pollexensis n. sp.

Acknowledgements. I gratefully acknowledge L. DesutterGrandcolas (MNHN) and T. Robillard (MNHN) for fruitful discussions and for their help in improving the manuscript, and for allowing the study of MNHN collections specimens. I thank the National Parks and the forestry services of both Mauritius and la Réunion for giving me access to the protected areas: $\mathrm{Na}$ tional Parks and Conservation Service (Mauritius), particularly M. Allet, P. Moollee and K. Ruhomaun; the Office National des Forêts (ONF) and particularly A. Brondeau (Réunion); the Mauritian Wildlife Fundation (MWF), particularly V. Tataya, N. Cole and A. Releaux; the Parc National de la Réunion, particularly M. Hoarau. I am indebted to all the colleagues and friends who helped me in the field: C. Baider (Mauritius Herbarium MSIRI), N. Cliquenois (Majunga, Madagascar), B. Devaux (ONF), V. Florens (University of Mauritius), A. Franck (CIRAD Réunion), S. Ganeshan (MSIRI), the Lambelin family, J. Rochat (Insectarium de la Réunion), D. Strasberg (Université de la Réunion) who also identified the foot plants, Ben Warren (Université de la Réunion), all the volunteers and wards of the MWF, and my father who joined most the fieldtrips. I thank particularly N. Cliquennois, wizard in chasing orthopteroids, who collected $M$. parvotibialis n. sp. male holotype. I thank R. Stebbings (CZM) for the pictures of Gryllapterus tomentosus holotype. I thank also P. Matyot (Seychelles Broadcasting Corporation) and S. Boucher (Lyman Museum), the former for stating me his collect of Gryllapterus tomentosus; the latter for the loan of these specimens, deposited in Keith Kevan's collection. I acknowledge J.-H. Lignot (Institut Pluridisciplinaire Hubert Curien, DEPE, UMR 7168, Strasbourg) and U. Ziegler (Institute of Anatomy, University of Zurich) for the use of the scan electron microscope of their laboratories. The field trips in la Réunion in 2001 and 2005 have been supported by the Germaine Cousin grant (Société Entomologique de France), and by the CIRAD Réunion, respectively. The collecting trips in Mauritius and offshore islands (2008-2009) have been funded by the BIOTAS project, ANR-06-BDIV-002.

\section{References}

Atkinson R., Sevathian J.C. 2005. A guide to the plants in Mauritius. Mauritian Wildlife Fundation, Vacoa, Mauritius, 188 p.

Bolívar I. 1912. No. XVI. - Orthoptera: Acrydiidae, Phasgonuridae, Gryllidae. (Percy Sladen Trust Expedition to the Seychelles) Transactions of the Linnean Society of London, 2nd series, Zoology 15: 263-292.

Chopard L. 1931. Résultats scientifiques du voyage aux Indes Orientales Néerlandaises de LL.AA.RR. le Prince et la Princesse Léopold de Belgique. Gryllidae et Gryllacrididae. Mémoires du Muséum d'Histoire Naturelle de Belgique (hors série) 4: 3-22.

Chopard L. 1945. Orthoptéroïdes recueillis dans les montagnes du Cameroun par la mission Lepesme, Paulian, Villiers. Revue Française d'Entomologie 11: 156-178.

Chopard L. 1958. Les Orthopteroides des Comores. Mémoires de l'Institut Scientifique de Madagascar, Série E 10: 3-40.

Chopard L. 1967. Contribution à la faune du Congo (Brazzaville). Mission A. Villiers et A. Descarpentries. L. Orthoptères, Grylloidea. Bulletin de l'Institut Fondamental d'Afrique Noire, Série A 29(2): 758-776.

Desutter-Grandcolas L. 2003. Phylogeny and the evolution of acoustic communication in extant Ensifera (Insecta, Orthoptera). Zoologica Scripta 32: 525-561.

Eades D.C., Otte D. 2008. Orthoptera Species File Online. Version 2.0/3.3. <http://Orthoptera.SpeciesFile.org>

Gorochov A.V. 1982. Novoe podsemeystvo sverchkov (Orthoptera, Gryllidae) iz Indo-Malayskoy oblasti [A new subfamily of crickets (Orthoptera, Gryllidae) from Indo-Malayan region], p.147-151 in: Zhivotnyj mir Vietnama [Animals of Vietnam]. Nauka, Moskow.

Gorochov A.V. 2004. Review of the subfamily Pteroplistinae (Orthoptera Gryllidae). Memorie della Societa Entomologica Italiana 82: 379-396.

Gorochov A.V. 2006. New and little known crickets of the subfamily phalangopsinae (Orthoptera, Gryllidae): 3. Indonesia, the Philippines, and Seychelles. Entomological Review 86(4): 438-448.

Gorochov A.V., Warchalowska-Sliwa E. 2004. On some morphological and karyological problems of the generic classification of Landrevinae (Orthoptera, Gryllidae) with descriptions of two new species. Journal of Orthoptera Research 13(1): 149-154.

Hugel S. 2005. Redécouverte du genre Pyrgacris à l'île de la Réunion : description du mâle de Pyrgacris descampsi Kevan, 1975 (Orthoptera, Caelifera). Bulletin de la Société Entomologique de France 110(2): 153159.

Kirby W.F. 1906. A synonymic catalogue of Orthoptera. Vol. II. Orthoptera Saltatoria. Part I. (Achetidae et Phasgonuridae). The Trustees of the British Museum, London, 562 p.

Otte D., Alexander R.D. 1987. The Australian crickets. Academy of Natural Sciences of Philadelphia Monograph 22: 1-477.

Otte D. 1988. Bark crickets of the Western Pacific region (Gryllidae: Pteroplistinae). -Proceedings of the Academy of Natural Sciences of Philadelphia 140: 281-334.

Ragge D. R., Reynolds W.J. 1998. The songs of the grasshoppers and crickets of western Europe. Harley Books, Colchester, Essex, 591 p.

Saussure H. de 1877. Mélanges Orthoptérologiques Tome 2. Fascicule V: Gryllides, $1^{\text {ère }}$ partie. Mémoires de la Société d'Histoire Naturelle de Genève 25: 1-352. 


\section{Addendum}

A recent fieldtrip has allowed to record an additional Landrevinae species from Mauritius.

\section{Creolandreva pollexensis $\mathrm{n} . \mathrm{sp}$. (figs. 65, 66, 67; tab. 8)}

Holotype. Male. Indian Ocean, Mascarene archipelago, Mauritius, Port Louis District, le Pouce, 733 m alt.; 20¹2'13"S 57³1'43”E; 8.V.2009; S. Hugel, MNHN-ENSIF2065.

Description. Very similar to C. brachyptera n. sp., differs from it by the shape of the male epiproct and the male genitalia.

Male. Male terminal tergites: epiproct much narrower than in C. brachyptera n. sp. (comparison in figs. 67 and 68). Male genitalia. Different from those of C. brachyptera n. sp.: pseudepiphallus with acute apex; dorsal cavity wide (figs. 65, 66).

Female. Unknown.

Etymology. After the type locality Le Pouce: "pollex" in Latin.
In most crickets, the character differences between C. brachyptera and C. pollexensis are strong enough to distinguish two species. I therefore tentatively consider them as distinct species, but additional specimens would be required to confirm this hypothesis.

Biology. The male holotype has been collected within a dead section of an unidentified shrub (Syzygium sp.?). Juveniles possibly belonging to the same species have been observed during night hours walking on barks of various trees. In the type locality, most trees dead sections are full of exotic ants, suggesting a possible competition for this "niche".

More generally, on both Réunion and Mauritius, Landrevinae species are lacking on trees invaded by exotic ants or termites. This might explain the lack of Landrevinae on managed plots, where most trees dead sections are often full of exotic ants or termites.

Table 8. Measurements (mm) of Creolandreva pollexensis n. g., n. sp.

\begin{tabular}{|c|c|c|c|c|c|c|c|c|c|c|c|c|c|c|}
\hline & \multirow{2}{*}{$\begin{array}{c}\text { Body } \\
\text { L }\end{array}$} & \multicolumn{2}{|c|}{ Head } & \multicolumn{3}{|c|}{ Thorax } & \multicolumn{3}{|c|}{ Tibia } & \multicolumn{3}{|c|}{ Femora } & \multirow{2}{*}{ Bt III } & \multirow{2}{*}{$\begin{array}{c}\text { FW } \\
\mathrm{L}\end{array}$} \\
\hline & & $\mathrm{L}$ & W & $\mathrm{L}$ & W & $\mathrm{H}$ & I & II & III & I & II & III & & \\
\hline$\delta$ Holotype & 11.5 & 1.7 & 2.3 & 1.9 & 2.7 & 1.0 & 2.3 & 2.4 & 4.0 & 2.4 & 2.5 & 6.3 & 2.1 & 2.9 \\
\hline
\end{tabular}
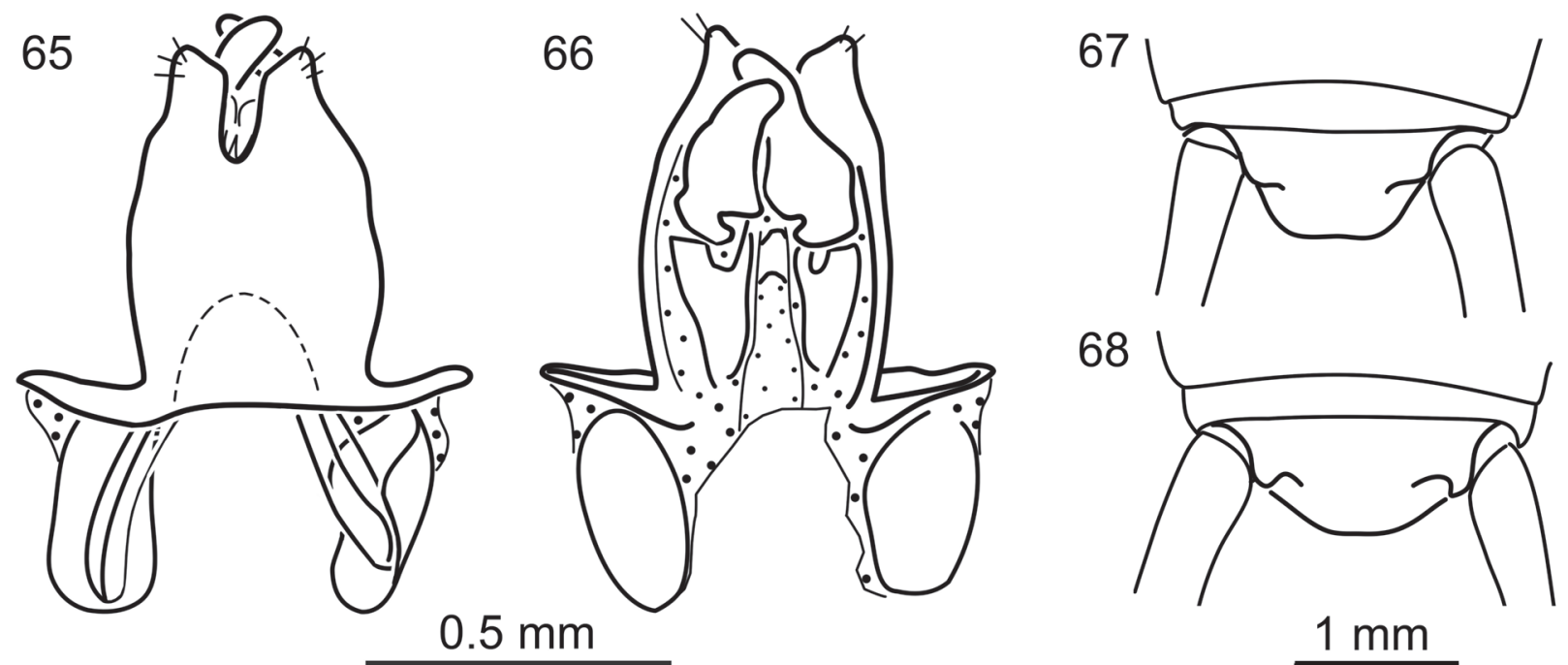

Figure 65-68

65, male genitalia of Creolandreva pollexensis n. g., n. sp. in dorsal view; 66, idem in ventral views; 67, terminal abdominal tergites of $C$. pollexensis n. g., n. sp. and, 68, C. brachyptera n. g., n. sp. 